\title{
Microstructural Stability of a Self-Ion Irradiated Lanthana-Bearing Nanostructured Ferritic Steel
}

Somayeh Pasebani ${ }^{a, b}$, Indrajit Charit ${ }^{a, b, 1}$, Jatuporn Burns $^{b, c}$, Sultan Alsagabi ${ }^{a, d}$, Darryl P. Butt ${ }^{b, c}$, James I. Cole ${ }^{b, e}$, Lloyd M. Price and Lin Shao $^{f}$

${ }^{a}$ Department of Chemical and Materials Engineering, University of Idaho, Moscow, ID 83844, USA

${ }^{\mathrm{b}}$ Center for Advanced Energy Studies, Idaho Falls, ID 83401, USA

${ }^{c}$ Department of Materials Science and Engineering, Boise State University, Boise, ID 83725, USA

${ }^{\mathrm{d}}$ Atomic Energy Research Institute, King Abdulaziz City for Science and Technology, Riyadh, Saudi Arabia

${ }^{\text {e }}$ Idaho National Laboratory, Idaho Falls, ID 83401, USA

${ }^{\mathrm{f}}$ Department of Nuclear Engineering, Texas A\&M University, College Station, TX 77843, USA

\begin{abstract}
High number density of thermally stable nanofeatures is expected to impart excellent high temperature strength and irradiation stability in nanostructured ferritic steels (NFSs) which have potential applications in advanced nuclear reactors. A lanthana-bearing NFS (14LMT) developed via mechanical alloying and spark plasma sintering was used in this study. The sintered samples were irradiated by $\mathrm{Fe}^{2+}$ ions to 10,50 and $100 \mathrm{dpa}$ at $30^{\circ} \mathrm{C}$ and $500^{\circ} \mathrm{C}$. Microstructural and mechanical characteristics of the irradiated samples were studied using different microscopy techniques and nanoindentation, respectively. Overall morphology and number density of the nanofeatures remained unchanged after irradiation. Average radius of nanofeatures in the irradiated sample $\left(100 \mathrm{dpa}\right.$ at $\left.500^{\circ} \mathrm{C}\right)$ was slightly reduced. A notable level of irradiation hardening and enhanced dislocation activity occurred after ion irradiation except at $30^{\circ} \mathrm{C}$ and $\geq 50$
\end{abstract}

\footnotetext{
${ }^{1}$ Corresponding Author (I. Charit)

E-mail - icharit@uidaho.edu; phone - +1-208-885-5964; fax: +1-208-885-7462 
dpa. Other microstructural features like grain boundaries and high density of dislocations also provided defect sinks to assist in defect removal.

Keywords: Nanostructured ferritic steels; ODS steels; lanthanum oxide; spark plasma sintering; heavy ion irradiation 


\section{Introduction}

Improvements in efficiency, safety and sustainability of the advanced nuclear reactors require fuel cladding materials and structural components that possess superior mechanical properties and microstructural stability under extreme conditions including high radiation damage (about 200 displacement per atom or dpa) and high temperatures (about $700^{\circ} \mathrm{C}$ ) [1-4]. Nanostructured ferritic steels (NFSs), which is a unique sub-class of oxide dispersion strengthened (ODS) steels, are considered potential candidate materials for fuel cladding applications in Gen-IV fission reactors due to their high radiation resistance and high creep strength at elevated temperatures [5, 6]. NFSs such as MA957 (Fe-14Cr-1Ti-0.25Mo-0.25 $\left.\mathrm{Y}_{2} \mathrm{O}_{3}\right)$ and 14YWT (Fe-14Cr-0.4Ti-3W$0.25 \mathrm{Y}_{2} \mathrm{O}_{3}$ ) are typically produced by mechanical alloying (MA) of pre-alloyed or elemental powder mixture and subsequent powder consolidation via hot extrusion or hot isostatic pressing (HIP) $[3,7]$. Microstructure of a NFS contains a high number density of thermally stable dispersion strengthening nanofeatures (also known as nanoclusters or NCs) enriched in $\mathrm{Y}-\mathrm{Ti}-\mathrm{O}$ or $\mathrm{Y}-\mathrm{Al}-\mathrm{O}$ that are resistant to radiation damage up to $800^{\circ} \mathrm{C}$ [8]. These nanofeatures, approximately 2-5 $\mathrm{nm}$ in diameter, provide high tensile and creep strength at elevated temperatures and appear to trap helium in fine bubbles limiting void swelling [3, 9, 10].

A comprehensive review on the development of irradiation resistant steels can be found in Ref. [9]. Microstructure, mechanical properties, thermal and irradiation stability of various ODS steels and NFSs under heavy ion irradiation have been studied by various researchers. They found these materials highly resistant to radiation damage $[1,6,11,12]$. In our previous study [13], the potential of using an alternative rare earth (RE) oxide in processing a new NFS was investigated by replacing $\mathrm{Y}_{2} \mathrm{O}_{3}$ with $\mathrm{La}_{2} \mathrm{O}_{3}$. Thus, an alloy with a nominal composition of $\mathrm{Fe}-$ $14 \mathrm{Cr}-1 \mathrm{Ti}-0.3 \mathrm{Mo}-0.5 \mathrm{La}_{2} \mathrm{O}_{3}(\mathrm{wt} . \%)$ was developed and was termed as 14LMT. In addition to 
altering the RE constituent in the chemical composition, the traditional consolidation methods such as HIP and extrusion were replaced by spark plasma sintering (SPS) [14]. It utilizes uniaxial force and pulsed (on-off) direct electrical current (DC) under vacuum to rapidly sinter the powder. Because of direct heating by the Joule mechanism, high heating rates can be obtained. This tends to enhance densification over grain growth and accelerates diffusion while maintaining intrinsic properties of nanopowders in their fully dense compact [15]. SPS has many advantages over processing by HIP including accurate control of sintering energy as well as high sintering rate, excellent reproducibility, safety and reliability [16].

Stability of NCs under irradiation is critical. It is known that collision cascades can eject solute atoms from NCs and change their physical characteristics [17]. Irradiation experiments are required in order to understand the stability of NCs. Since neutron irradiation experiment was outside the scope of the present study, the developed NFS was exposed to self-ion $\left(\mathrm{Fe}^{2+}\right)$ irradiation. Subsequently, the irradiated material was characterized by transmission electron microscopy and nanoindentation. Was et al. [18] reported that ion irradiation experiments, especially at high doses, can be tailored by controlling He production and damage rate in such a way so as to emulate in-reactor radiation damage. In the current study, the self-ion $\left(\mathrm{Fe}^{2+}\right)$ irradiation experiments were conducted on the developed 14LMT NFS specimens at both room $\left(30{ }^{\circ} \mathrm{C}\right)$ and elevated temperature $\left(500{ }^{\circ} \mathrm{C}\right)$ as a function of ion dose $(0,10,50$ and $100 \mathrm{dpa})$.

\section{Experimental Procedures}

\subsection{Material Processing}

All powders were procured from American Elements Inc., except the Mo powder that was procured from Micron Metal Powder Inc. The starting constituent powders including Fe (99.9 wt.\%, average powder size of $40 \mu \mathrm{m}), \mathrm{Cr}(99.8$ wt.\%, average powder size of $5 \mu \mathrm{m})$, Ti $(99.7$ 
wt.\%, average powder size of $26 \mu \mathrm{m}), \mathrm{La}_{2} \mathrm{O}_{3}(99.99$ wt.\%, average powder size of $40 \mathrm{~nm}$ ) and Mo (99.9 wt. \%, average powder size of 1-2 $\mu \mathrm{m})$ were mixed in the nominal proportion of $\mathrm{Fe}-$ $14 \mathrm{Cr}-1 \mathrm{Ti}-0.3 \mathrm{Mo}-0.5 \mathrm{La}_{2} \mathrm{O}_{3}$ (wt.\%). High-energy ball milling was performed in an air-cooled Spex $8000 \mathrm{M}$ mixer/mill for $10 \mathrm{~h}$ using 316 stainless steel balls ( $8 \mathrm{~mm}$ in diameter) as the milling media. High energy ball milling was performed at a speed of 1725 r.p.m. with lateral movement. The vial was vibrated at an amplitude of $50 \mathrm{~mm}$ and frequency of $20 \mathrm{~Hz}$ during milling. A milling batch consisted of $100 \mathrm{~g}$ steel balls and $10 \mathrm{~g}$ powder giving a ball to powder ratio (BPR) of 10:1. The milled powder was consolidated via SPS by using a Dr. Sinter Lab SPS-515S machine (SPS Syntex Inc., Kanagawa, Japan). A Tri-Gemini cylindrical graphite die with an inner diameter of $12.7 \mathrm{~mm}$ and an outer diameter of $38 \mathrm{~mm}$ was used. The inner surfaces of the dies and radial surfaces of punches were covered with a graphite foil $(0.25 \mathrm{~mm}$ in thickness $)$ to facilitate the removal of the sintered specimens. In order to inhibit the diffusion of carbon from the punches and graphite foil to the powder mixture, a thin niobium foil (thickness of $0.06 \mathrm{~mm}$ ) was placed between the powder and the graphite foils. The dies were wrapped in a graphite felt with $4 \mathrm{~mm}$ thickness to minimize heat loss by thermal radiation. The milled powder was sintered at $950^{\circ} \mathrm{C}$ for 45 min under vacuum $\left(7 \times 10^{-3}\right.$ Torr or $\left.0.9 \mathrm{~Pa}\right)$. A pulsed DC current with pattern of 12-2 (current on for $12 \mathrm{~ms}$ and off for $2 \mathrm{~ms}$ ), a heating rate of $100^{\circ} \mathrm{C} / \mathrm{min}$ and a pressure of approximately $80 \mathrm{MPa}$ (10 kN force) were used here. The final product was in the form of a disk with diameter of $12.5 \mathrm{~mm}$ and thickness of $8 \mathrm{~mm}$.

\subsection{Heavy Ion Irradiation}

Prior to irradiation, specimens with diameter of about $12 \mathrm{~mm}$ and thickness of $1 \mathrm{~mm}$ were mechanically polished using standard metallographic procedures of grinding and polishing followed by a final polish in a vibratory polisher using $0.05 \mu \mathrm{m}$ alumina slurry for up to $48 \mathrm{~h}$. 
The specimens were irradiated with iron ions $\left(\mathrm{Fe}^{2+}\right)$ at the Texas A\&M Ion Beam Laboratories using 1.7 MV Tandetron accelerator. The specimens were irradiated to 10, 50 and 100 dpa (1 dpa was equal to $5.75 \times 10^{14}$ ions.cm ${ }^{-2}$ ) with an ion flux of $1.88 \times 10^{12}$ ions.cm ${ }^{-2}$ s, at temperatures of $30{ }^{\circ} \mathrm{C}$ and $500{ }^{\circ} \mathrm{C}$, respectively. Samples were mounted on a heating stage using silver paint. Sample temperatures were adjusted by changing the current of a resistance heater, through a feedback system linked to thermal couples attached on sample surfaces. The beam uniformity and heating were monitored by using an infrared camera. Due to complexity from thermal electron emission, the beam intensity was monitored by a Faraday cup positioned before the heat stage. Considering that thermal annealing at $500{ }^{\circ} \mathrm{C}$ only may lead to structural evolutions, one control sample was added to the heat stage without exposure to the ion beam. Figure 1 shows the damage profiles calculated by using the Stopping and Range of Ions in Matter (SRIM) code [19]. The dpa peak is about $0.9 \mu \mathrm{m}$ below the surface.

The microstructural analysis was focused on the region at the depth of about $400 \mathrm{~nm}$ to about $800 \mathrm{~nm}$. The selection of this region considers the necessity to avoid the surface defect-depleted region due to defect sink property of a free surface $(<200 \mathrm{~nm})$ and the region affected by defect imbalance [20]. The momentum transfer during ion irradiation favors the forward direction, leading to a difference between spatial distributions of vacancies and interstitials. The depth profile of interstitials is slightly deeper than that of vacancies. Thus, excess vacancies are created near the surface and excess interstitials are created near the Fe projected range. Furthermore, the extra $\mathrm{Fe}$ atoms introduced act as injected interstitials. In the present study, we intentionally avoided the peak damage region since void swelling is locally suppressed due to the above effects. 


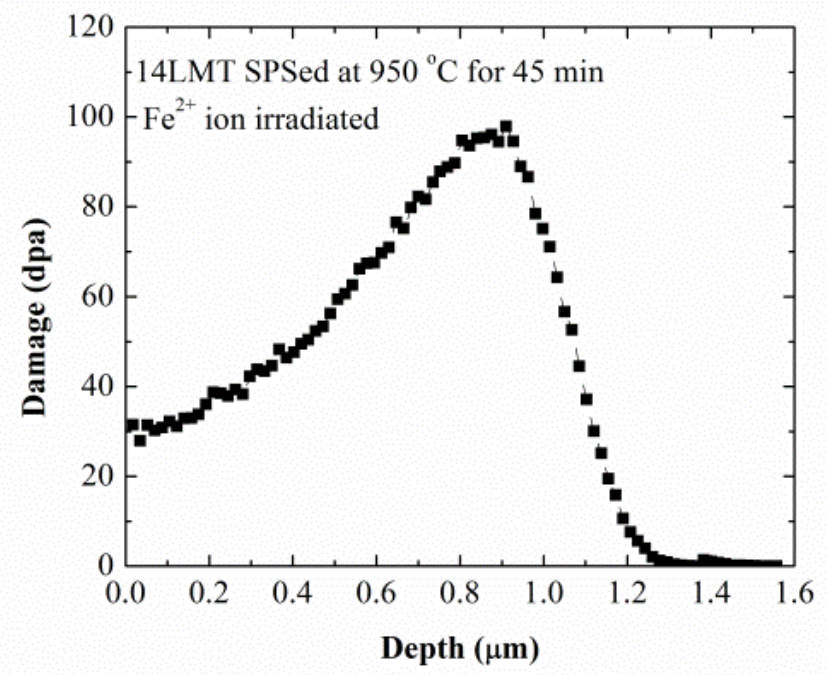

Figure 1. The $\mathrm{Fe}^{+2}$ irradiation damage profile of 14LMT alloy obtained using SRIM.

\subsection{Microstructural Studies}

\subsubsection{Transmission electron microscopy}

A focused ion beam (FIB) FEI Quanta 3D FEG instrument with a Ga-ion source was used to prepare specimens for transmission electron microscopy (TEM) characterization. During the FIB process, a protective layer of Pt was deposited on the specimen surface using a voltage of 5 $\mathrm{kV}$ and current of $3.0 \mathrm{nA}$. Bulk milling (using $30 \mathrm{kV}$ and $7.0 \mathrm{nA}$ ) and rough cleaning (using 30 $\mathrm{kV}$ and $3.0 \mathrm{nA}$ ) were conducted on each edge of the protected area. A lamella was welded on an Omniprobe tip by Pt deposition to be lifted out. Following that, the lamella was mounted on a copper grid and milled sequentially with $3.0 \mathrm{nA}, 1.0 \mathrm{nA}, 0.3 \mathrm{nA}$ and $0.1 \mathrm{nA}$ at a voltage of 30 $\mathrm{kV}$. Final cleaning was performed using $48.0 \mathrm{pA}$ current at a voltage of $5 \mathrm{kV}$ and $27.0 \mathrm{pA}$ at a voltage of $2 \mathrm{kV}$ to remove gallium contamination and damage from the specimen. The final thickness of lamella varied between 50-100 nm. A FEI Tecnai TF30 FEG STEM operating at $300 \mathrm{kV}$ was used to characterize the sample microstructure and chemistry. 


\subsubsection{Atom probe tomography studies}

The FIB technique was used to prepare specimens for atom probe tomography (APT). The APT analysis was carried out using a CAMECA LEAP 4000X HR operating in voltage mode at a specimen temperature of $50-60 \mathrm{~K}$ and $20 \%$ of the standing voltage pulse fraction. The atom maps were reconstructed using CAMECA IVAS 3.6 software. The maximum separation cluster algorithm was used to identify the composition of NCs. Maximum separation between solute atoms is defined as $d_{\max }$ whereas $L$ is the maximum separation of additional elements and $E$ is the erosion distance for removal of atoms near the cluster/matrix interface. An $N_{\min }$ (the minimum size of a cluster) value of $10-15, d_{\max }$ values of $0.6-0.8 \mathrm{~nm}, L$ values of $0.4-0.5 \mathrm{~nm}$ and $E$ values ranging from $0.3-0.5 \mathrm{~nm}$ were chosen based on procedures described comprehensively in the literature $[12,21]$. Background noise correction was applied to the mass spectrum and the matrix composition was calculated by excluding those atoms defined as a cluster based on the maximum separation method. The size of NCs was estimated from the radius of gyration $\left(R_{g}\right)$ which is the average distance between each atom and the center of a corresponding cluster [22]. This was applied to APT datasets, each containing 8-10 million ions.

\subsection{Nanoindentation}

A Hysitron Nanoindenter (model TI-950 TriboIndenter) with a Berkovich tip (radius of 200 $\mathrm{nm}$ and tip angle of $142.35^{\circ}$ ) was used for hardness measurements at room temperature. Prior to indentation, a fused silica reference was used to calibrate the tip geometry with a total of 100 indents. The indentations were made on the irradiated area for all six specimens $\left(30^{\circ} \mathrm{C}\right.$ for 10,50 and $100 \mathrm{dpa}$ and $500{ }^{\circ} \mathrm{C}$ for 10,50 and $100 \mathrm{dpa}$ ) and on un-irradiated areas of the specimens. Samples were mounted on a magnet and indents were produced in a direction normal to the sample surface with constant time segment using a multi-cycling method. One hundred cycles 
were obtained with 2 s holding time. For each condition, more than 15 arrays of indentations were collected. The data sets with the best fit were used to plot the depth dependence of hardness changes. The data were collected from $100 \mathrm{~nm}$ to $1000 \mathrm{~nm}$ depth.

\section{Results and discussion}

\subsection{Microstructural examination and analyses}

\subsubsection{Transmission electron microscopy}

The TEM bright field (BF) micrograph in Fig. 2(a) exhibits a representative view of the irradiation damage layer, protective Pt layer and the analyzed region in 14LMT alloy. The TEM BF micrographs in Figs. 2(b-g) show representative microstructures of 14LMT alloy unirradiated and irradiated. The microstructure in Figs. 2(b-g) consisted primarily of nanograins with a high density of grain boundaries, dislocations and precipitates. The grain structure including grain size remained unchanged after irradiation at 30 and $500^{\circ} \mathrm{C}$ up to $100 \mathrm{dpa}$, and no recrystallization or grain growth were observed after irradiation at higher temperature. The analysis of selected area diffraction (SAD) patterns showed neither the formation of any radiation-induced particles or new phases nor was there evidence of an amorphous phase or the formation of voids. 

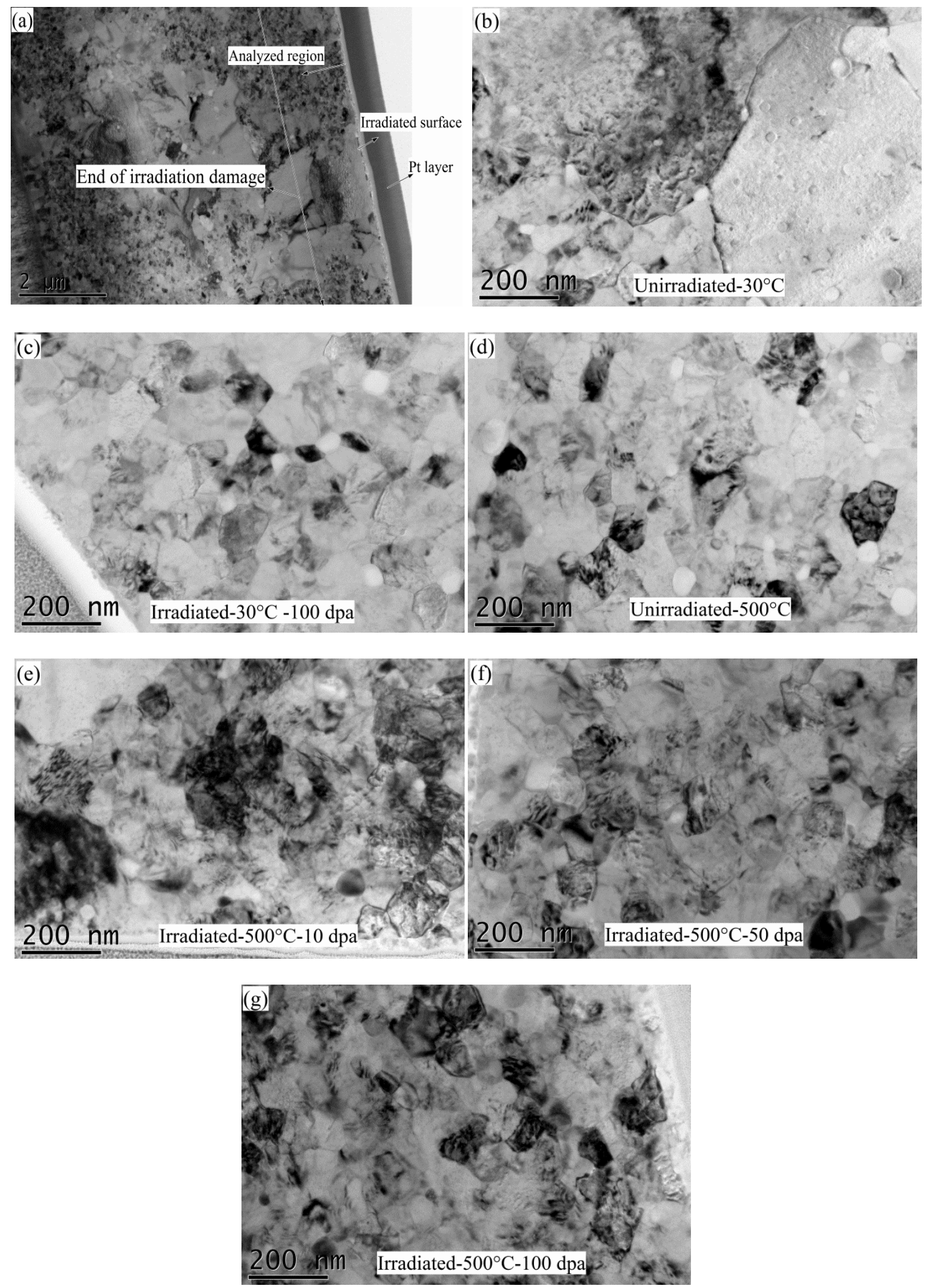

Figure 2. The overview of the microstructure of 14LMT alloy: (a) the irradiation damage and analyzed region, (b) unirradiated, (c) irradiated at $30^{\circ} \mathrm{C}$ for $100 \mathrm{dpa}$, (d) unirradiated at $500^{\circ} \mathrm{C}$, (e) irradiated at $500^{\circ} \mathrm{C}$ for $10 \mathrm{dpa}$, (f) irradiated at $500^{\circ} \mathrm{C}$ for $50 \mathrm{dpa}$ and $(\mathrm{g})$ irradiated at $500^{\circ} \mathrm{C}$ for $100 \mathrm{dpa}$ 
The dislocation structures in the unirradiated condition, irradiated conditions at $30^{\circ} \mathrm{C}$ for 100 dpa, unirradiated at $500^{\circ} \mathrm{C}$ and irradiated at $500^{\circ} \mathrm{C}$ for 10,50 and 100 dpa are all shown in Figs. 3(a-f), respectively. The micrographs were obtained under two-beam conditions close to a major zone axis. A high density of dislocations and nano-sized dark dots were identified. There was no evidence of dislocation loops or tangled networks. All the micrographs were obtained at similar beam conditions $(g=\{011\})$. The "dark dots" in the unirradiated sample shown in Fig. 3(a), could be due to FIB artifacts. 

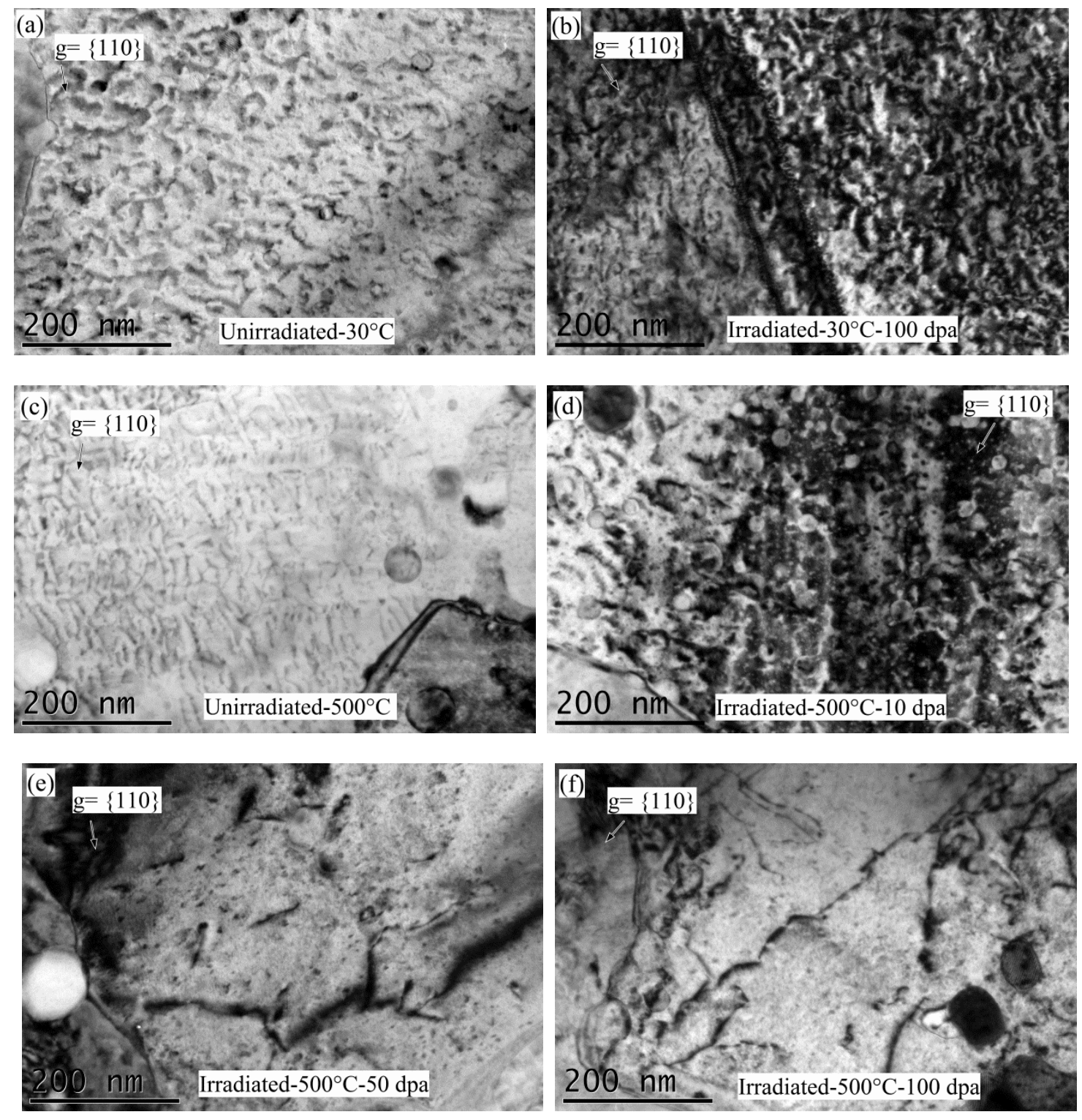

Figure 3. TEM images of dislocations in 14LMT alloy showing: (a) unirradiated, (b) irradiated at $30^{\circ} \mathrm{C}$ for $100 \mathrm{dpa}$, (c) unirradiated at $500^{\circ} \mathrm{C}$, (d) irradiated at $500^{\circ} \mathrm{C}$ for $10 \mathrm{dpa}$, (e) irradiated at $500^{\circ} \mathrm{C}$ for $50 \mathrm{dpa}$ and (f) irradiated at $500^{\circ} \mathrm{C}$ for $100 \mathrm{dpa}$

Dislocation densities estimated from Figs. $3(\mathrm{a}-\mathrm{f})$ are listed in Table 1. The dislocation density increased with higher ion doses regardless of irradiation temperature. The changes in dislocation density under irradiation are attributed to the high surface stresses caused by the high dose of implanted surfaces during the ion irradiation process [24]. In unirradiated samples, a slight reduction in dislocation density was observed at $500^{\circ} \mathrm{C}$ due to thermal dislocation annihilation, but the recovery was not extensive since the dislocations were pinned by 
nanoparticles as will be shown later. Dislocations that are effectively pinned by nanoparticles along with a high density of grain boundaries could provide strong sink sites for radiation induced point defects such as vacancies and interstitials [4, 25].

Table 1. Dislocation density in various 14LMT samples as measured from TEM micrographs

\begin{tabular}{lcc}
\hline Sample & Condition & Dislocation Density $\left(\mathbf{m}^{-2}\right)$ \\
\hline Unirradiated & As processed & $3.7 \pm 0.3 \times 10^{14}$ \\
Irradiated Region & $30{ }^{\circ} \mathrm{C} / 100 \mathrm{dpa}$ & $6.0 \pm 0.2 \times 10^{14}$ \\
Unirradiated Region & $500{ }^{\circ} \mathrm{C} / 10 \mathrm{dpa}$ & $2.7 \pm 0.3 \times 10^{14}$ \\
Irradiated Region & $500{ }^{\circ} \mathrm{C} / 10 \mathrm{dpa}$ & $2.8 \pm 0.8 \times 10^{14}$ \\
Irradiated Region & $500{ }^{\circ} \mathrm{C} / 50 \mathrm{dpa}$ & $4.2 \pm 0.4 \times 10^{14}$ \\
Irradiated Region & $500{ }^{\circ} \mathrm{C} / 100 \mathrm{dpa}$ & $5.1 \pm 0.2 \times 10^{14}$ \\
\hline
\end{tabular}

The oxide particles of 14LMT alloy before and after irradiation are shown in Figs. 4(a-f). No strong contrast was observed between the nanoparticles and the matrix in the BF mode. However, the particle size did not undergo any significant irradiation coarsening or refining. In summary, the matrix/particles interface, shape, morphology and size of the particles did not show significant changes under Fe ion irradiation to $100 \mathrm{dpa}$. Particle size distribution histograms of the unirradiated and irradiated samples are shown in Figs. 5(a-f). In order to provide ample statistical data, at least 300 particles were used to generate the histograms. No significant particle size reduction was observed as indicated in Figs. 5(a-f). However, the fraction of particles smaller than $2 \mathrm{~nm}$ at higher doses appeared to be more obvious after irradiation at $500{ }^{\circ} \mathrm{C}$ than at $30{ }^{\circ} \mathrm{C}$. Higher magnification micrographs were utilized for constructing the plots shown in Figs. 5(a-f), and mainly focused on the smallest particles. Particles larger than $36 \mathrm{~nm}$ were not included in the plots even though they were observed in some of the micrographs obtained at 
lower magnification. Furthermore, due to the resolution limit of the TEM and FIB sample preparation, particles smaller than $1 \mathrm{~nm}$ were not easily detected.
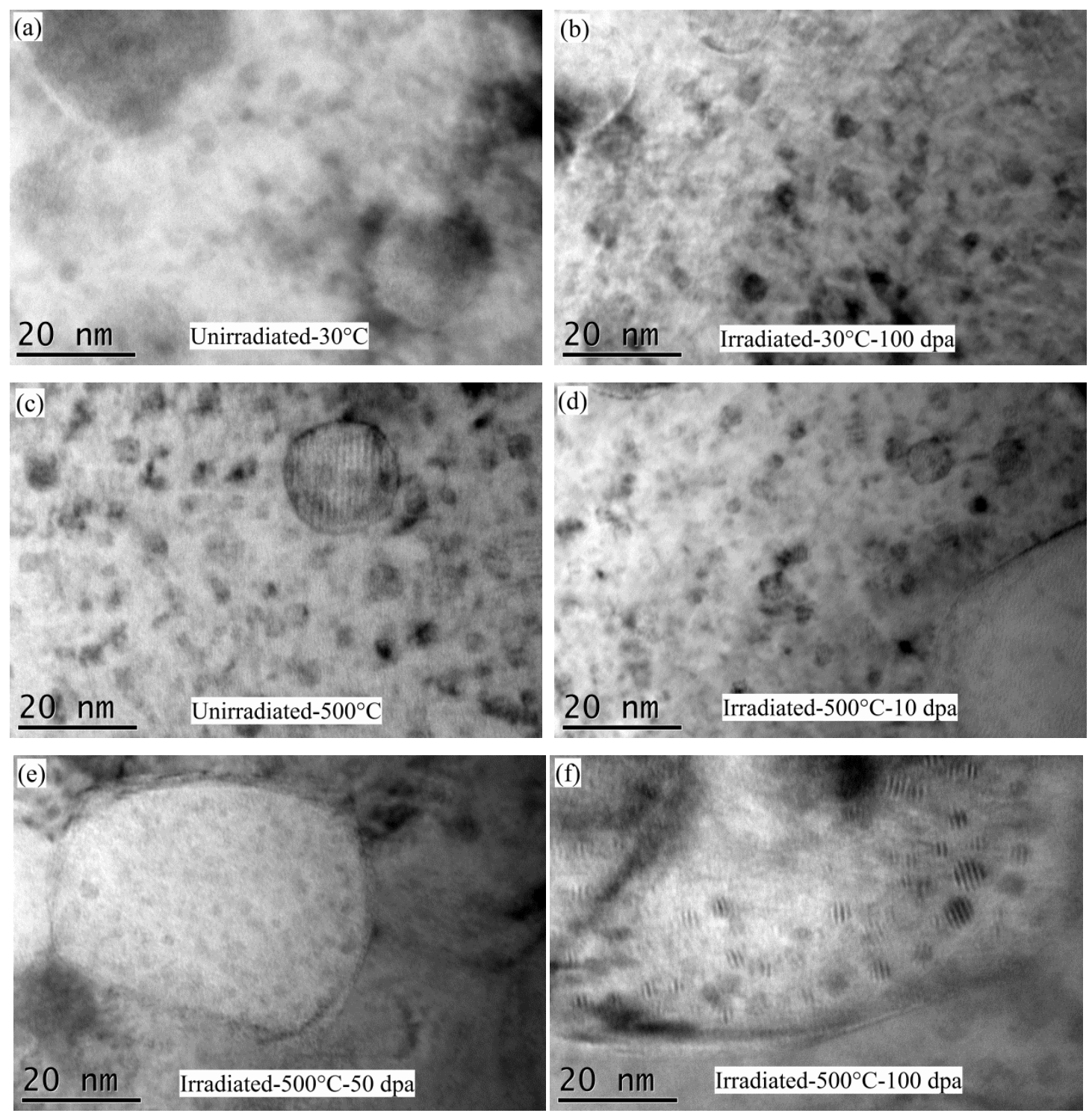

Figure 4. TEM images of the oxide particles observed in 14LMT alloy: (a) unirradiated, (b) irradiated at $30{ }^{\circ} \mathrm{C}$ for $100 \mathrm{dpa}$, (c) unirradiated at $500{ }^{\circ} \mathrm{C}$, (d) irradiated at $500{ }^{\circ} \mathrm{C}$ for $10 \mathrm{dpa}$, (e) irradiated at $500^{\circ} \mathrm{C}$ for $50 \mathrm{dpa}$ and (f) irradiated at $500{ }^{\circ} \mathrm{C}$ for $100 \mathrm{dpa}$ 

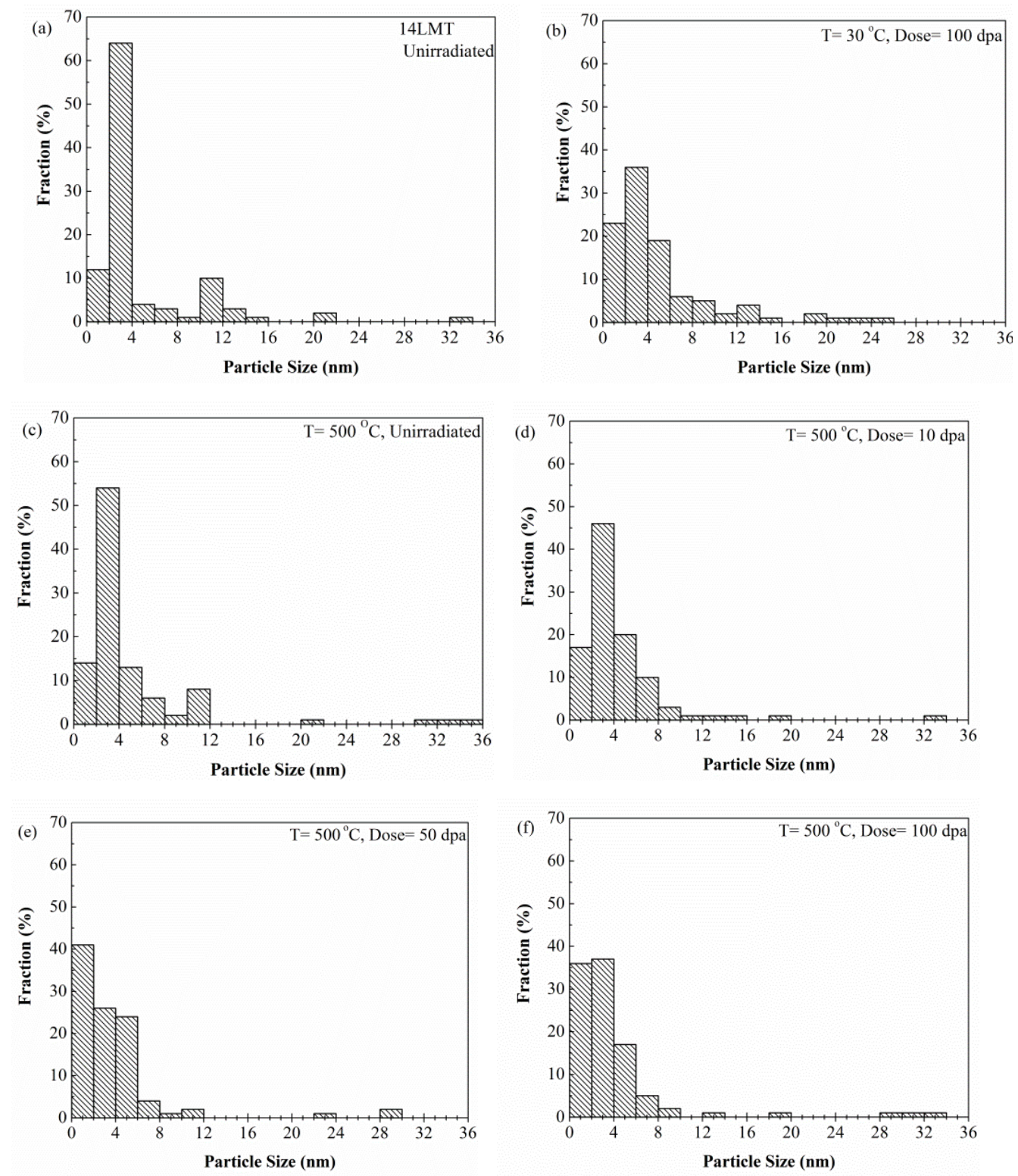

Figure 5. Particle size (radius) distribution for 14LMT samples: (a) unirradiated, (b) irradiated at $30{ }^{\circ} \mathrm{C}$ for $100 \mathrm{dpa}$, (c) unirradiated at $500{ }^{\circ} \mathrm{C}$, (d) irradiated at $500{ }^{\circ} \mathrm{C}$ for $10 \mathrm{dpa}$, (e) irradiated at $500{ }^{\circ} \mathrm{C}$ for $50 \mathrm{dpa}$ and (f) irradiated at $500{ }^{\circ} \mathrm{C}$ for $100 \mathrm{dpa}$

Figure 6(a) shows a high angle annular dark field (HAADF) STEM micrograph obtained at a relatively low magnification. Both the irradiated region (from surface to $1.6 \mu \mathrm{m}$ depth) and the analyzed region are marked. The nanoparticles distributed in the irradiated samples were clearly observed in the Z-contrast micrographs shown in Figs. 6(b-d). No significant change in morphology or chemical composition of the particles was noted in the Z-contrast micrographs. 
Fig. 6(e) shows an energy dispersive spectroscopy (EDS) spectrum of a $10 \mathrm{~nm}$ particle from the samples irradiated at $500{ }^{\circ} \mathrm{C}$ with 100 dpa dose whereas Fig. 6(f) shows an EDS spectrum obtained from the matrix of the same sample showing strong peaks of Fe and $\mathrm{Cr}$.

The particle was composed of $\mathrm{Fe}, \mathrm{Cr}, \mathrm{La}$ and $\mathrm{O}$. Because the oxide particles were located in a foil thicker than the particle size, the EDS data included matrix information. The larger particles were primarily $\mathrm{Cr}$-Ti-oxide or $\mathrm{La}-\mathrm{Cr}$-oxide and did not show any irradiation induced alteration in the chemical composition. The $14 \mathrm{LMT}$ unirradiated sample $\left(500^{\circ} \mathrm{C}\right)$ and $14 \mathrm{LMT}$ sample irradiated at $500^{\circ} \mathrm{C}$ for 100 dpa were analyzed by the energy filtered TEM (EFTEM) method. The EFTEM micrographs in Figs. $7(\mathrm{a}-\mathrm{h})$ show particles that were enriched in Ti and $\mathrm{O}$ but depleted of Fe. The particles smaller than $10 \mathrm{~nm}$ were enriched in $\mathrm{La}$, but it was difficult to resolve in EFTEM due to sample thickness. The nanoparticles in both unirradiated and irradiated specimens appeared to remain chemically stable.

The main contribution of nanoparticles is to enhance mechanical strength at high temperature by stabilizing subgrains and dislocation configurations. Secondly, these particles can inhibit and suppress void swelling along with the ferritic structure. Furthermore, the rastering mode of irradiation utilized in this study is not expected to produce detectable void swelling.
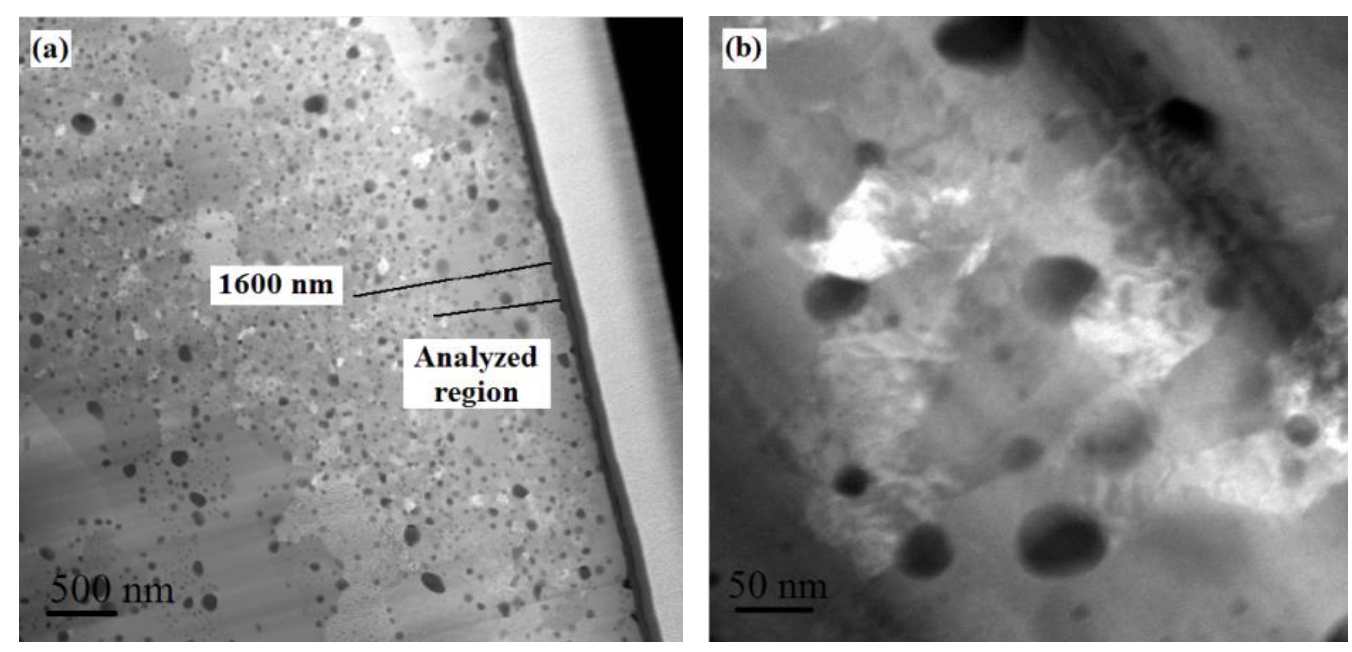

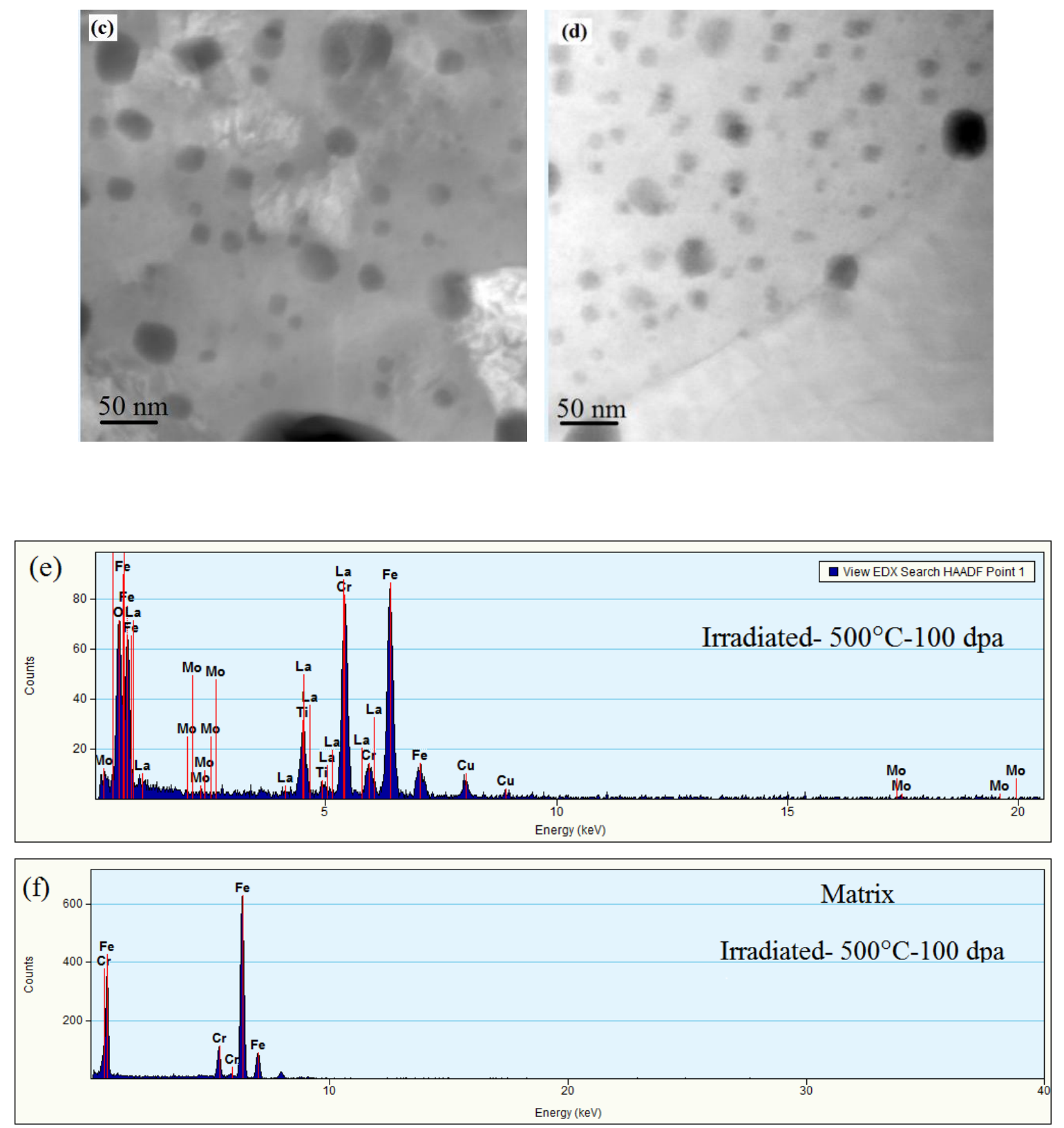

Figure 6. HAADF STEM micrograph overall view of the specimen: (a) the overview of the sample, (b) unirradiated, (c) unirradiated at $500^{\circ} \mathrm{C}$, (d) irradiated at $500^{\circ} \mathrm{C}$ for $100 \mathrm{dpa}$, (e) an EDS spectrum from oxide particles in sample irradiated at $500^{\circ} \mathrm{C}$ for $100 \mathrm{dpa}$ and (f) an EDS spectrum from matrix in sample irradiated at $500^{\circ} \mathrm{C}$ for $100 \mathrm{dpa}$ 

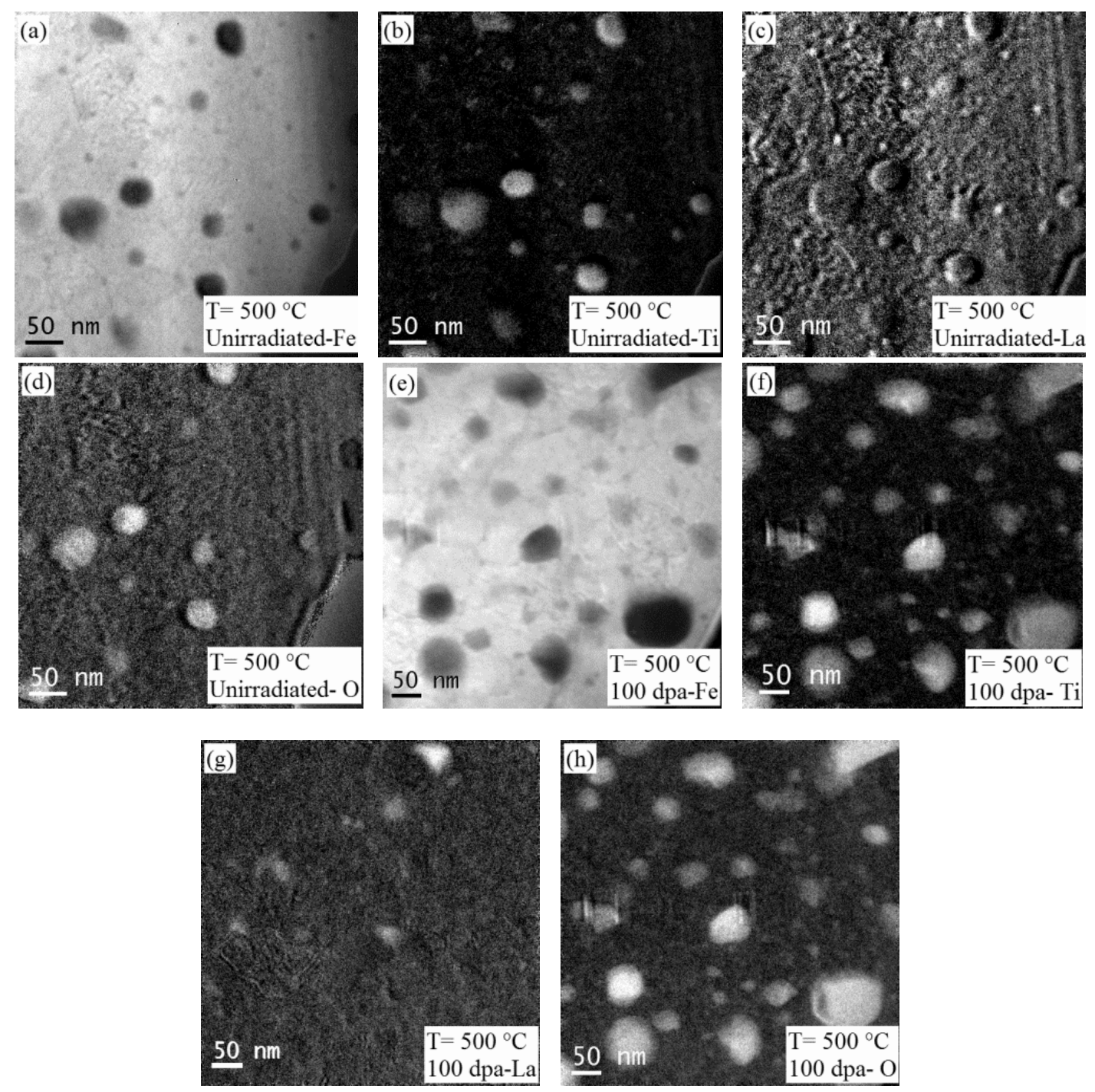

Figure 7. EFTEM maps for 14LMT alloy: (a) unirradiated -Fe, (b) unirradiated -Ti, (c) unirradiated -La, (d) unirradiated-O, (e) $100 \mathrm{dpa}-\mathrm{Fe}$, (f) $100 \mathrm{dpa}-\mathrm{Ti}$, (g) $100 \mathrm{dpa}-\mathrm{La}$ and (h) 100 dpa-O (the temperature condition for all micrographs was at $500^{\circ} \mathrm{C}$ and the energy edges used in the images are: La-M, O-K, Fe-L, Ti-L).

\subsubsection{APT studies}

High resolution TEM (HRTEM) micrographs combined with APT maps of the NCs are shown in Figs. 8(a-e). Number density of the $\mathrm{Cr}^{-}$, Ti-, La-, O-enriched NCs in the 14LMT alloy (unirradiated) was estimated to be $1.2 \times 10^{24} \mathrm{~m}^{-3}$ with an average Guinier radius of $1.5 \pm 0.3 \mathrm{~nm}$. The HAADF STEM micrographs obtained from NCs and some larger oxide particles along with APT results of $14 \mathrm{LMT}$ sample irradiated at $500{ }^{\circ} \mathrm{C}$ for 100 dpa are shown in Figs. $8(\mathrm{f}-\mathrm{j})$. 
Number density of the $\mathrm{Cr}-, \mathrm{Ti}-, \mathrm{La}-, \mathrm{O}-$ enriched NCs in the $14 \mathrm{LMT}$ sample irradiated at $500{ }^{\circ} \mathrm{C}$ for 100 dpa was estimated to be $1.2 \times 10^{24} \mathrm{~m}^{-3}$ with an average Guinier radius of $1.3 \pm 0.2 \mathrm{~nm}$. A summary of APT analysis results including the average radius, number density and compositions of the clusters are provided in Table 2. The average atomic composition of NCs was slightly affected by ion irradiation. The concentration of Fe, Mo and Ti in NCs slightly decreased, and the concentration of $\mathrm{Cr}$ and $\mathrm{La}$ in NCs showed an increase after irradiation at $500{ }^{\circ} \mathrm{C}$. During the formation of collision cascades at $500^{\circ} \mathrm{C}$, the solute atoms, such as $\mathrm{Cr}$ and $\mathrm{Ti}$, were ejected from the NCs and re-diffused from the matrix to the NCs. Certain et al. [17] suggested that under high temperature irradiation back diffusion of solutes from the matrix to the NCs becomes possible, thus leading to "dynamic stability" in NCs. On the contrary, the instability of NCs after irradiation at $-75^{\circ} \mathrm{C}$ was associated with low or no diffusion of solute atoms indicating that NCs are more (dynamically) stable at higher temperatures rather than lower temperatures. The reason for the increase in $\mathrm{Cr}$ concentration and decrease in the Ti concentration in NCs after irradiation is not clear at this point. At $500^{\circ} \mathrm{C}$ the diffusion coefficient of $\mathrm{Cr}$ in $\alpha-\mathrm{Fe}$ is approximately 2.5 times greater than that of Ti in $\alpha-F e$. For $\mathrm{Cr}$ diffusion in $\alpha-\mathrm{Fe}, Q=55,400 \pm 700 \mathrm{cal} / \mathrm{mol}$ and $D_{o}$ $=0.64 \pm 0.07 \mathrm{~cm}^{2} \mathrm{~s}^{-1}[26]$ and for Ti diffusion in $\alpha-\mathrm{Fe}, Q=59,200 \mathrm{cal} / \mathrm{mol}$ and $D_{o}=3.15 \mathrm{~cm}^{2} \mathrm{~s}^{-1}$ [27]. The difference in diffusivities seems relevant to the observed difference in $\mathrm{Cr}$ and $\mathrm{Ti}$ concentrations.

The La+Ti:O ratio in NCs before and after irradiation was 0.98 and 1.15, respectively, implying a slight increase in La+Ti:O ratio after irradiation. For calculating La+Ti:O ratio, the influence of the matrix has been removed here. The number density of NCs remained unchanged after irradiation up to $100 \mathrm{dpa}$. The radius of NCs exhibited a slight refining after high temperature irradiation. The APT maps and the size distribution histograms of NCs in a smaller 
volume of $14 \mathrm{LMT}$ alloy unirradiated and irradiated at $500^{\circ} \mathrm{C}$ with 100 dpa are presented in Figs. $9(\mathrm{a}-\mathrm{h})$. The size of NCs before and after irradiation did not show any significant changes except slight refinement. Size distribution histograms of NCs for both unirradiated and irradiated 14LMT alloys were constructed from several APT data sets and are illustrated in Fig. 9(d) and Fig. 9(h), respectively. The size distribution histograms for both unirradiated and irradiated alloys at $500^{\circ} \mathrm{C}$ for $100 \mathrm{dpa}$ were similar. However, the latter histogram showed a slight decrease in the size of NCs. Pareige et al. [28] studied the stability of NCs in 12YWT after irradiation to $0.7 \mathrm{dpa}$ with $150 \mathrm{keV} \mathrm{Fe}$ ions at $300^{\circ} \mathrm{C}$. The size, number density, and chemical composition of the NCs were also similar to those observed in unirradiated specimens. However, under neutron irradiation, the instability of oxide particles in terms of morphology and crystallinity might be an issue as reported by Monnet et al. [29]. The microstructural evolution characteristics including nanoparticles of different ODS alloys after ion and neutron irradiation are summarized in Table 3.
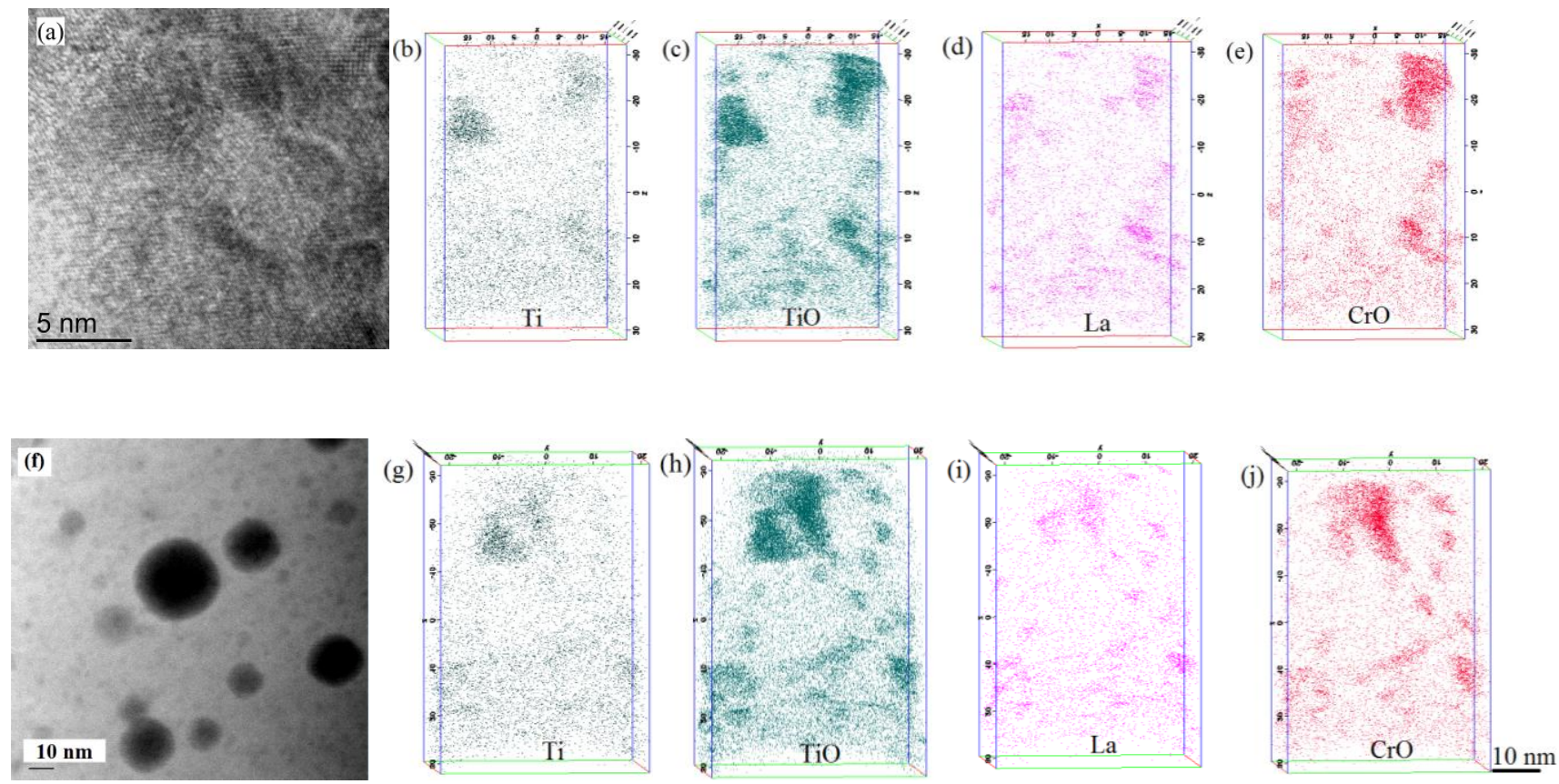
Figure 8. (a) HRTEM micrograph obtained from 14LMT unirradiated specimen prior to APT, corresponding (b) Ti map, (c) TiO map, (d) La map, (e) CrO map; (f) HAADF STEM micrograph obtained from 14LMT irradiated at $500^{\circ} \mathrm{C}$ for 100 dpa prior to APT, corresponding (g) Ti map, (h) TiO map, (i) La map, and (j) $\mathrm{CrO}$ map (analyzed volume was $40 \times 40 \times 80 \mathrm{~nm}^{3}$ )

(a)

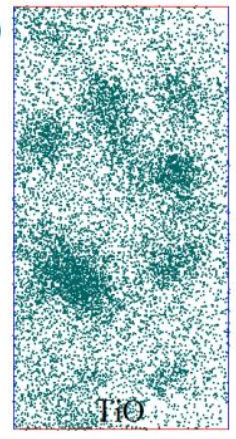

(e)

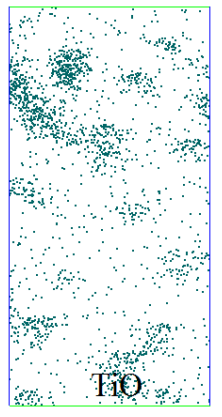

(b)

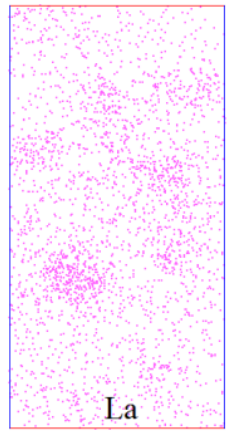

(f)

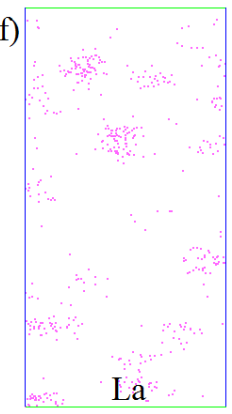

(c)

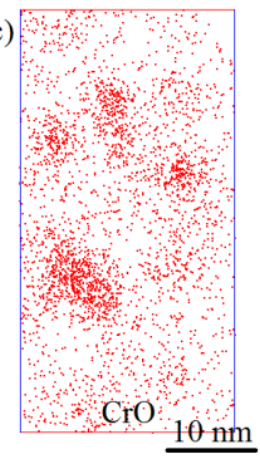

(g)

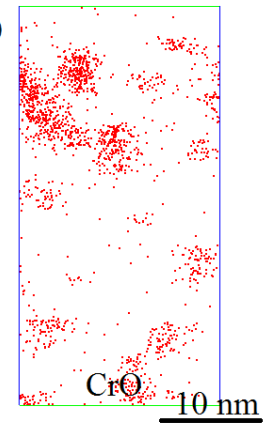

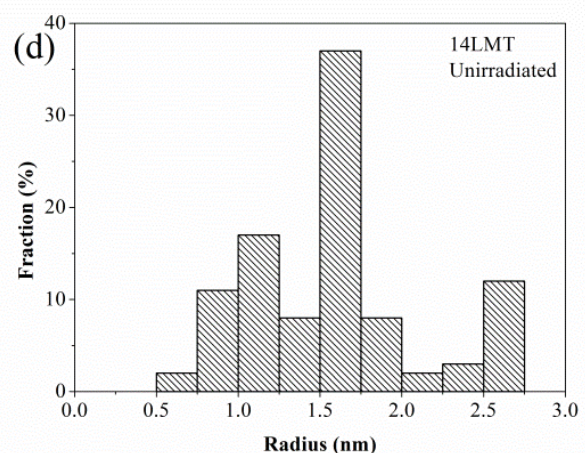

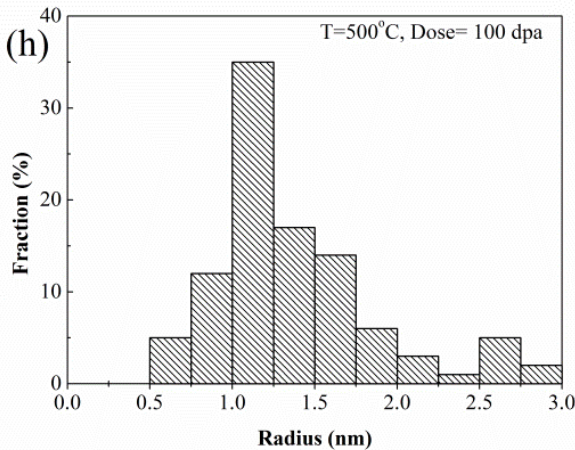

Figure 9. The APT maps of unirradiated specimen showing NCs enriched in: (a) TiO, (b) La, (c) CrO, (d) radius distribution histogram of NCs for the unirradiated 14LMT, (e) the APT maps of irradiated showing NCs enriched in

(e) $\mathrm{TiO}$, (f) $\mathrm{La}$, (g) $\mathrm{CrO}$ and (h) NCs radius distribution histogram for $14 \mathrm{LMT}$ irradiated at $500{ }^{\circ} \mathrm{C}$ for $100 \mathrm{dpa}$

Table 2. Summary of the average radius, number density and average cluster composition obtained from APT results of 14LMT alloy samples unirradiated and irradiated at $500{ }^{\circ} \mathrm{C}$ for $100 \mathrm{dpa}$

\begin{tabular}{|c|c|c|c|c|c|c|c|c|}
\hline \multirow[t]{2}{*}{ Condition } & \multirow{2}{*}{$\begin{array}{c}\text { Ave. } \\
\text { Radius } \\
(\mathrm{nm})\end{array}$} & \multirow{2}{*}{$\begin{array}{l}\text { No. Den. } \\
\left(10^{24} \mathrm{~m}^{-3}\right)\end{array}$} & \multicolumn{6}{|c|}{ Ave. Cluster Composition (at.\%) } \\
\hline & & & $\mathrm{Cr}$ & $\mathrm{O}$ & $\mathrm{Ti}$ & $\mathrm{La}$ & Mo & $\mathrm{Fe}$ \\
\hline Unirradiated & $1.5 \pm 0.2$ & 1.2 & $8.9 \pm 2.2$ & $35.25 \pm 3$ & $17.8 \pm 2$ & $6.89 \pm 0.8$ & $0.06 \pm 0.03$ & $31.1 \pm 6.0$ \\
\hline $\begin{array}{l}100 \mathrm{dpa} \text { at } \\
500^{\circ} \mathrm{C}\end{array}$ & $1.3 \pm 0.2$ & 1.2 & $12.2 \pm 3$ & $36.6 \pm 2$ & $15.4 \pm 3$ & $8.8 \pm 2.1$ & $0.02 \pm 0.02$ & $26.8 \pm 5.2$ \\
\hline
\end{tabular}


Table 3. Summary of irradiation response of some ODS steels under ion and neutron irradiation

\begin{tabular}{|c|c|c|c|c|}
\hline Alloy & Composition (wt.\%) & Irradiation Conditions & Irradiation Response & Ref. \\
\hline K1 & $\begin{array}{c}\mathrm{Fe}-19 \mathrm{Cr}-0.3 \mathrm{~W}-0.3 \mathrm{Ti}-0.35 \mathrm{Y}_{2} \mathrm{O}_{3} \\
\mathrm{Fe}-19 \mathrm{Cr}-2 \mathrm{~W}-4 \mathrm{Al}-0.3 \mathrm{Ti}-0.35 \mathrm{Y}_{2} \mathrm{O}_{3}\end{array}$ & $\begin{array}{l}\text { 6.4 MeV Fe} \\
\text { Dose: } 50 \mathrm{dpa} \\
\text { Temp: } 670^{\circ} \mathrm{C}\end{array}$ & $\begin{array}{l}\text { Grain morphology, grain size } \\
\text { and fine dispersed oxides were } \\
\text { unchanged. The complex Y- } \\
\text { Ti-O-enriched and Y-Al-O- } \\
\text { enriched particles were found to } \\
\text { be stable. }\end{array}$ & [6] \\
\hline 9Cr-ODS & $\mathrm{Fe}-9.19 \mathrm{Cr}-2 \mathrm{~W}-0.21 \mathrm{Ti}-0.33 \mathrm{Y}_{2} \mathrm{O}_{3}$ & $\begin{array}{l}5 \mathrm{MeV} \text { Ni ions } \\
\text { Dose: } 5,50 \text { and } 150 \mathrm{dpa} \\
\text { Temp: } 350-700^{\circ} \mathrm{C}\end{array}$ & $\begin{array}{l}\text { The microstructre did not } \\
\text { change and was dominated by } \\
\text { dense dislocations, precipitates } \\
\text { and yttrium oxide particles. }\end{array}$ & [1] \\
\hline 14YWT & $\mathrm{Fe}-14 \mathrm{Cr}-3 \mathrm{~W}-4 \mathrm{Al}-0.4 \mathrm{Ti}-0.25 \mathrm{Y}_{2} \mathrm{O}_{3}$ & $\begin{array}{c}5 \mathrm{MeV} \mathrm{Ni}^{+2} \text { ions } \\
\text { Dose: } 5,50 \text { and } 100 \text { dpa } \\
\text { Temp: }-75,300,450 \text { and } 600{ }^{\circ} \mathrm{C}\end{array}$ & $\begin{array}{l}\text { The Y-Ti-O-enriched particles } \\
\text { were stable after irradaitation at } \\
\text { higher temperature due to } \\
\text { dynamic stability; however, } \\
\text { NCs were unstable at lower } \\
\text { temperature due to low } \\
\text { diffusion of the ejected solutes. }\end{array}$ & [17] \\
\hline 12YWT & $\mathrm{Fe}-12.3 \mathrm{Cr}-3 \mathrm{~W}-0.39 \mathrm{Ti}-0.25 \mathrm{Y}_{2} \mathrm{O}_{3}$ & $\begin{array}{l}150 \mathrm{keV} \mathrm{Fe} \text { ions } \\
\text { Dose: } 0.7 \mathrm{dpa} \\
\text { Temp: } 300^{\circ} \mathrm{C}\end{array}$ & $\begin{array}{l}\text { The size, number density and } \\
\text { composition of NCs remained } \\
\text { unchanged after irradiation. } \\
\text { Neither dissolution nor } \\
\text { coarsening of particles } \\
\text { occurred. }\end{array}$ & {$[28]$} \\
\hline MA957 & $\mathrm{Fe}-14 \mathrm{Cr}-1 \mathrm{Ti}-0.3 \mathrm{Mo}-0.25 \mathrm{Y}_{2} \mathrm{O}_{3}$ & $\begin{array}{l}300 \mathrm{keV} \text { of Fe ions } \\
\text { Dose: } 21 \mathrm{dpa} \\
\text { Temp: } 25^{\circ} \mathrm{C} \\
1 \mathrm{MeV} \text { of } \mathrm{Kr} \text { ions } \\
\text { Dose: } 200 \mathrm{dpa} \\
\text { Temp: } 500^{\circ} \mathrm{C}\end{array}$ & $\begin{array}{l}\text { High density of black dot } \\
\text { damage and developing loops } \\
\text { as well as particle } \\
\text { amorphization and degradation } \\
\text { was reported. }\end{array}$ & {$[32]$} \\
\hline MA957 & $\mathrm{Fe}-14 \mathrm{Cr}-1 \mathrm{Ti}-0.3 \mathrm{Mo}-0.25 \mathrm{Y}_{2} \mathrm{O}_{3}$ & $\begin{array}{l}\text { Dual and single ion irradiation } \\
\text { with } 1 \text { appm He } \\
\text { Dose: } 150 \mathrm{dpa} \\
\text { Temp: } 450 \text { and } 650^{\circ} \mathrm{C} \\
3 \mathrm{MeV} \mathrm{Ni}^{+} \\
\text {Dose: } 150 \mathrm{dpa} \\
\text { Temp: } 525^{\circ} \mathrm{C}\end{array}$ & $\begin{array}{l}\text { The dislocation structure and } \\
\text { dispersion was stable, } \\
\text { especially under single-ion } \\
\text { irradiation, while recovery was } \\
\text { observed in dual-ion irradiated } \\
\text { specimens. } \\
\text { The oxide particles were stable } \\
\text { under irradaition. }\end{array}$ & {$[33]$} \\
\hline DT2203Y05 & $\mathrm{Fe}-13 \mathrm{Cr}-2.2 \mathrm{Ti}-1.5 \mathrm{Mo}-0.5 \mathrm{Y}_{2} \mathrm{O}_{3}$ & $\begin{array}{c}52 \mathrm{MeV} \mathrm{Cr}{ }^{+6} \text { and } 4 \mathrm{MeV} \alpha \\
\text { particles } \\
\text { Dose: } 50 \text { dpa and } \mathrm{He} 600 \mathrm{appm} \\
\text { Temp: } 475{ }^{\circ} \mathrm{C}\end{array}$ & $\begin{array}{c}\text { Yttria phase remained } \\
\text { unchanged and dislocation } \\
\text { density remained high and } \\
\text { stable. There was a possibility } \\
\text { of Laves phase and } \alpha^{\prime} \\
\text { formation. }\end{array}$ & {$[34]$} \\
\hline $\mathrm{FeCrAl}$ & $\mathrm{Fe}-20 \mathrm{Cr}-5.5 \mathrm{Al}-0.5 \mathrm{Ti}-0.5 \mathrm{Y}_{2} \mathrm{O}_{3}$ & $\begin{array}{c}2.5 \mathrm{MeV} \mathrm{Fe} \text { ions } \\
\text { Dose: } 31 \mathrm{dpa} \\
\text { Temp: room temperature and } \\
300^{\circ} \mathrm{C}\end{array}$ & $\begin{array}{c}\text { Size and composition of } \mathrm{Y}-\mathrm{Al}- \\
\text { O-enriched particles were } \\
\text { stable and formation of } \\
\text { nanocavities filled by He was } \\
\text { observed. }\end{array}$ & {$[35]$} \\
\hline
\end{tabular}


Eurofer97 $\quad \mathrm{Fe}-9.5 \mathrm{Cr}-0.65 \mathrm{~W}-0.15 \mathrm{Y}-0.2 \mathrm{Si}-$ $0.45 \mathrm{Mn}-0.21 \mathrm{~V}-0.04 \mathrm{Ta}-0.65 \mathrm{C}$

$16 \mathrm{Cr}$

MA 956

12Cr-ODS

F94 ODS

F 95 ODS

$18 \mathrm{Cr}-\mathrm{ODS}$

316-ODS

High $\mathrm{Cr}$

DY-ODS
$\mathrm{Fe}-19.4 \mathrm{Cr}-4.8 \mathrm{Al}-0.38 \mathrm{Ti}-0.58 \mathrm{Y}_{2} \mathrm{O}_{3}$

$\mathrm{Fe}-12.5 \mathrm{Cr}-2.5 \mathrm{~W}-0.25 \mathrm{Ti}-0.4 \mathrm{Y}_{2} \mathrm{O}_{3}$

$\mathrm{Fe}-11.8 \mathrm{Cr}-0.3 \mathrm{Ti}-1.93 \mathrm{~W}-0.24 \mathrm{Y}_{2} \mathrm{O}_{3}$ (MA in $\mathrm{He}$ )

$\mathrm{Fe}-11.8 \mathrm{Cr}-0.3 \mathrm{Ti}-1.93 \mathrm{~W}-0.24 \mathrm{Y}_{2} \mathrm{O}_{3}$ (MA in $\mathrm{Ar}$ )

$\mathrm{Fe}-18 \mathrm{Cr}-1 \mathrm{~W}-0.3 \mathrm{Ti}-0.6 \mathrm{Y}_{2} \mathrm{O}_{3}$

$\mathrm{Fe}-16.2 \mathrm{Cr}-13.6 \mathrm{Ni}-0.35 \mathrm{Y}_{2} \mathrm{O}_{3}$

$\mathrm{Fe}-13 \mathrm{Cr}-1.48 \mathrm{Mo}-0.08 \mathrm{Mn}-2 \mathrm{Ti}-$ $0.45 \mathrm{Y}-0.3 \mathrm{O}$
0.5-2 MeV

Dose: 2 dpa

Temp: $400{ }^{\circ} \mathrm{C}$

6.4 MeV Fe ions

Dose: $60 \mathrm{dpa}$

Temp: $650{ }^{\circ} \mathrm{C}$

123.4 MeV Ni ions

Dose: $0.7-1.8 \mathrm{dpa}$

Temp: $440{ }^{\circ} \mathrm{C}$

$33 \mathrm{keV} \mathrm{H}$ ion $50 \mathrm{ppm} / \mathrm{dpa}$

Dose: $15 \mathrm{dpa}$

Temp: 350,450 and $550{ }^{\circ} \mathrm{C}$

Fast neutrons (JOYO)

Dose: 7,2.5,14 and $15 \mathrm{dpa}$

Temp: $330,400,450$ and $500{ }^{\circ} \mathrm{C}$

$150 \mathrm{keV}$ in situ ion irradiation Dose: 4, 23, 45 and 48 dpa Temp: $500{ }^{\circ} \mathrm{C}$

$$
\begin{gathered}
\text { 10.5 MeV Fe } \\
\text { Dose: } 20 \text { dpa } \\
\text { Temp: } 250 \text { and } 380{ }^{\circ} \mathrm{C}
\end{gathered}
$$

$700 \mathrm{keV} \mathrm{Kr}^{2+}$

Dose: $100 \mathrm{dpa}$

Temp: $500{ }^{\circ} \mathrm{C}$ matrix became irregular due to
The oxide particles were stable during neutron irradiation with no evidence of growth and/or dissolution of the oxide particles. The heavier gas element in MA atmosphere is better than a lighter one in order to reduce irradiation-induced bubble coarsening. So, Ar was better than $\mathrm{He}$ in this study.

The oxide particles were stable and siginificant Mn segregation was observed at dislocations and grainboundaries with less density of oxide particles. Mn segregation could possibly contribute to irradiation induced hardening.

HRTEM and APT studies revealed that the size, shape and composition $\mathrm{Y}-\mathrm{Ti}-\mathrm{O}$-enriched complex dispersoids were stable.

Small voids and stable oxide particles were observed.

The oxide particles were stable but the interface between the dispersed oxide particle and the the irradiation. Hydrogen irradiation caused void formation.

$\mathrm{Y}-\mathrm{Ti}-\mathrm{O}-\mathrm{enriched}$ particles as small as $5 \mathrm{~nm}$ were stable up to 45 dpa. However, some larger oxides (> 20nm) seemed more affected by irradiation, showing evidences of interface and shape modifications.

Irradiation-induced dislocations and dislcoation loops were extensive.

Amorphizatin occurred in the oxides. The spherical shape and particle surface morphology may be altered.

[36] 
18Cr-ODS $\quad \mathrm{Fe}-18 \mathrm{Cr}-1 \mathrm{~W}-0.3 \mathrm{Ti}-0.5 \mathrm{Y}_{2} \mathrm{O}_{3}$

12Cr-ODS

KP4-ODS

alloy

14YWT

ODS ferrite-

DT

DY

EM10+

$\mathrm{Y}_{2} \mathrm{O}_{3}$
$92 \mathrm{MeV}$ Xe ions

Dose: $2.5 \mathrm{dpa}$ (flunece of $3.5 \times$ $10^{14} \mathrm{~cm}^{-2}$ )

Temp:27 and $507{ }^{\circ} \mathrm{C}$

Triple $\mathrm{Fe}^{+2}, \mathrm{He}^{+}, \mathrm{H}^{+}$irradiation (JANNUS)

Dose: $4.4 \mathrm{dpa}$

Fe $2.23 \times 10^{15}$ ions $/ \mathrm{cm}^{2}$ and $5.6 \times 10^{15}$ ions $/ \mathrm{cm}^{2} \mathrm{He}^{+}$and $\mathrm{H}^{+}$

Temp: $21^{\circ} \mathrm{C}$

$\mathrm{Fe}-15 \mathrm{Cr}-4 \mathrm{Al}-2 \mathrm{~W}-0.35 \mathrm{Y}_{2} \mathrm{O}_{3}$

$700 \mathrm{MeV}$ Bi ions:

Dose: $1.2 \times 10^{-3}, 4.8 \times 10^{-4}$

$167 \mathrm{MeV}$ Xe ions: $1.5 \times 10^{-2}$ and

Dose: $1 \times 10^{-3}$

Temp: $25^{\circ} \mathrm{C}$
$\mathrm{Fe}-14 \mathrm{Cr}-3 \mathrm{~W}-0.4 \mathrm{Ti}-0.25 \mathrm{Y}_{2} \mathrm{O}_{3}$

$\mathrm{Fe}-13 \mathrm{Cr}-2.2 \mathrm{Ti1} .5 \mathrm{Mo}-0.5 \mathrm{Y}_{2} \mathrm{O}_{3}$

$\mathrm{Fe}-12.9 \mathrm{Cr}-1.48 \mathrm{Mo}-2 \mathrm{Ti}-0.45 \mathrm{Y}-$

$0.3 \mathrm{O}$

$\mathrm{Fe}-8.6 \mathrm{Cr}-1.15 \mathrm{Mo}-0.51 \mathrm{Mn}-0.38 \mathrm{Si}-$ $0.18 \mathrm{Y}-0.13 \mathrm{O}$
$5 \mathrm{MeV} \mathrm{Ni}^{+2}$ ions

Dose: $100 \mathrm{dpa}$

Temp: 300,450 and $600{ }^{\circ} \mathrm{C}$

Neutron-Phenix

Dose: $80 \mathrm{dpa}$

Temp: $400-580{ }^{\circ} \mathrm{C}$

\section{Neutrons Phenix \\ Dose: 81 dpa \\ $1 \mathrm{MeV} \mathrm{He}$}

Dose: $0,54.8,75.6,79.3,78.8$ and 30.5

Temp: 400, 435,484,508, 532 and $580^{\circ} \mathrm{C}$
Shape, composition and size of the oxide particles remained unchanged. No dissolution of the particles were observed. Possible amorphization after irradiation at low temperature was observed.

Y-rich nanoparticles were stable and the crystalline structure was not altered.

Small oxide particles $(<5 \mathrm{~nm})$ remained crystalline in $\mathrm{Bi}$ irradiation, while subsurface regions in large (> $20 \mathrm{~nm})$ particles were amorphized.

Xe ion irradiation resulted in amorphization of small

$\mathrm{Y}_{4} \mathrm{Al}_{2} \mathrm{O}_{9}$ oxide particles while the amorphous bodies of large particles were found to contain small crystalline inclusions.

Size and number density of

NCs did not change especially at higher temperatures.

$\mathrm{Y}_{2} \mathrm{O}_{3}$ dissolved under neutron irradiation with the dose of 80 dpa.

Oxide particles were stable under He irradiation but a significant dissolution of oxides occurred under neutron irradiation (>60 dpa). The interfaces of oxide particles with the matrix became irregular, and a halo of fine oxides appeared around the larger oxides. The chemical composition of oxides altered losing $\mathrm{Al}$ and $\mathrm{Ti}$ from the NCs.
[42]

[44] 


\subsection{Nanomechanical Characterization}

Nanoindentation results for unirradiated and irradiated samples are included in Figs. 10(a-h). The hardness data were acquired at indentation depths of 100 to $1000 \mathrm{~nm}$ below the surface. All the samples showed a constant increase in hardness with higher doses. A minor annealing effect on dislocation structures was the likely reason for the slightly lower hardness values observed at $500^{\circ} \mathrm{C}$ compared to $30^{\circ} \mathrm{C}$, especially in unirradiated sample and in samples with lower doses. The sample irradiated at $100 \mathrm{dpa}$ and $500^{\circ} \mathrm{C}$ had hardness close to those of the sample irradiated at $30^{\circ} \mathrm{C}$ under the same dose. The irradiation hardening effect apparently was more dominant than the thermal annealing and dislocation annihilation effect. The estimated dislocation density for irradiated samples was consistent in relation to the nanoindentation results.
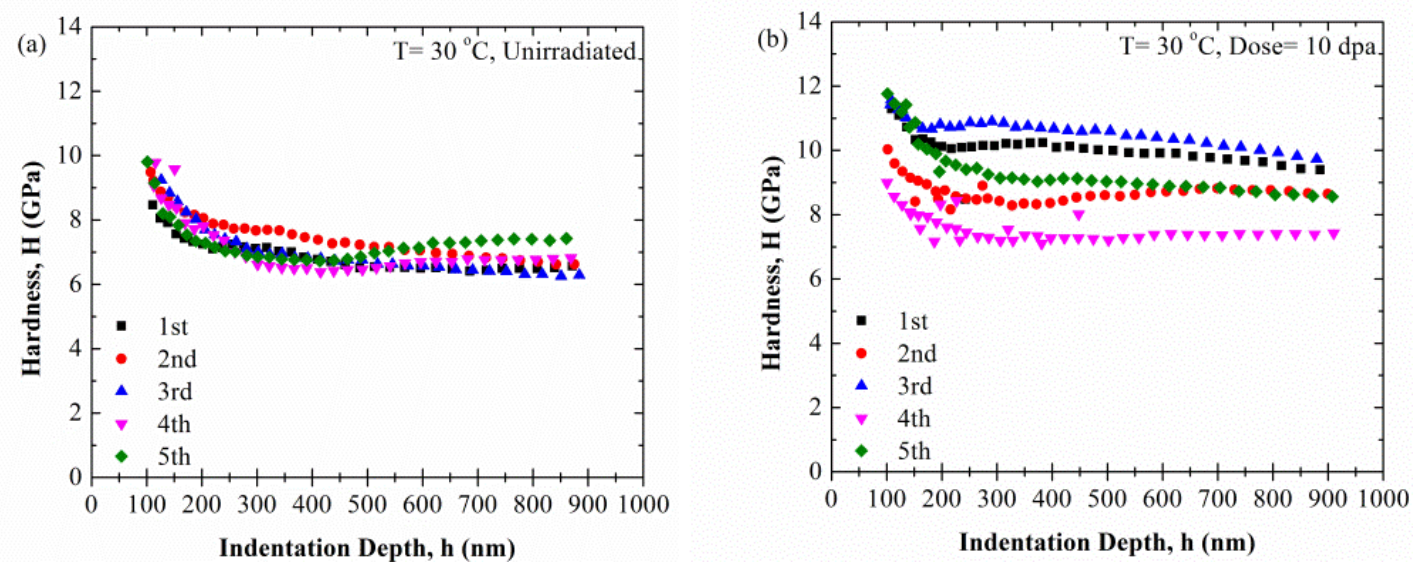

Figure 10. Nanoindentation results obtained by using the multi-cycling method: (a) unirradiated, (b) irradiated at $30^{\circ} \mathrm{C}$ for $10 \mathrm{dpa}$, (c) unirradiated at $30^{\circ} \mathrm{C}$ for $50 \mathrm{dpa}$, (d) irradiated at $30{ }^{\circ} \mathrm{C}$ for 100 dpa, (e) unirradiated at $500{ }^{\circ} \mathrm{C}$, (f) irradiated at $500{ }^{\circ} \mathrm{C}$ for $10 \mathrm{dpa}$, (g) irradiated at $500{ }^{\circ} \mathrm{C}$ for $50 \mathrm{dpa}$ and (h) irradiated specimen at $500{ }^{\circ} \mathrm{C}$ for $100 \mathrm{dpa}$ 

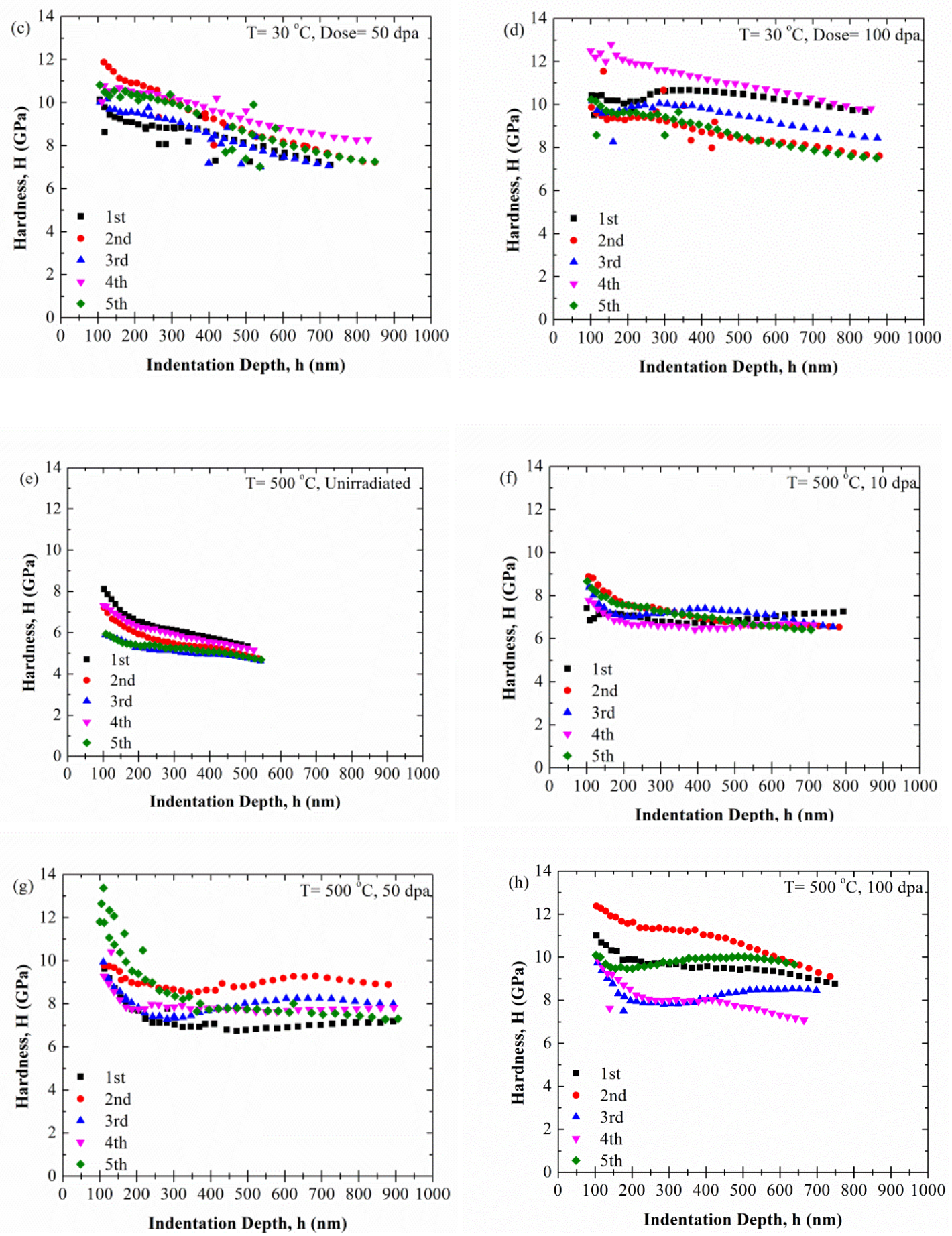

(Continued) Figure 5. Nanoindentation results obtained by using the multi-cycling method: (a) unirradiated, (b) irradiated at $30{ }^{\circ} \mathrm{C}$ for $10 \mathrm{dpa}$, (c) unirradiated at $30{ }^{\circ} \mathrm{C}$ for $50 \mathrm{dpa}$, (d) irradiated at 30 ${ }^{\circ} \mathrm{C}$ for $100 \mathrm{dpa}$, (e) unirradiated at $500{ }^{\circ} \mathrm{C}$, (f) irradiated at $500{ }^{\circ} \mathrm{C}$ for $10 \mathrm{dpa}$, (g) irradiated at $500{ }^{\circ} \mathrm{C}$ for $50 \mathrm{dpa}$ and $(\mathrm{h})$ irradiated specimen at $500{ }^{\circ} \mathrm{C}$ for $100 \mathrm{dpa}$ 
Figures 11(a-b) show the average nanoindentation hardness for samples irradiated at 30 and $500{ }^{\circ} \mathrm{C}$. In Fig. 11(a), the average hardness values increased significantly after 10 dpa and then slightly increased after 50 and $100 \mathrm{dpa}$, displaying an apparent saturation in hardness at approximately 50 dpa and above. As illustrated in Fig. 11(b), the average hardness values constantly increased at higher doses. The dependence of the ratio of $\mathrm{H}_{\text {irrad }}$ and $\mathrm{H}_{\text {unirrad }}$ (radiation hardening ratio) on indentation depth for irradiated samples at $30^{\circ} \mathrm{C}$ for $100 \mathrm{dpa}$ and at $500^{\circ} \mathrm{C}$ for 10, 50 and 100 dpa is illustrated in Fig. $11(\mathrm{c})$. For irradiation at $30^{\circ} \mathrm{C}$, there was a peak in value of $\mathrm{H}_{\text {irrad }} / \mathrm{H}_{\text {unirrad }}$ at an indentation depth of $200 \mathrm{~nm}$. The peak was observed at about $20 \%$ of damaged layer thickness, which is consistent with other reported studies $[30,31]$. The ratio of $\mathrm{H}_{\text {irrad }}$ and $\mathrm{H}_{\text {unirrad }}$ decreases when the implantation depth is less than the radius of hemispherical influence zone of the indentation. For irradiation at $500^{\circ} \mathrm{C}, \mathrm{H}_{\text {irrad }} / \mathrm{H}_{\text {unirrad }}$ constantly increased with indentation depth and radiation doses, and no peak was observed likely due to the lower hardness of unirradiated sample at $500^{\circ} \mathrm{C}$ because of thermal annihilation of dislocations. The hardness of unirradiated samples at $500^{\circ} \mathrm{C}$ was lower than the hardness of unirradiated sample at $30^{\circ} \mathrm{C}$. Since the irradiation depth is the same for all the samples, the radiation-hardening ratio at $500^{\circ} \mathrm{C}$ and $100 \mathrm{dpa}$ was found to be higher than the radiation hardening ratio at $30^{\circ} \mathrm{C}$ and 100 dpa. Furthermore, partially dynamic dislocation annihilation at $500{ }^{\circ} \mathrm{C}$ allowed for more dislocation storage capacity and therefore more hardening to occur at the same irradiation dose. 

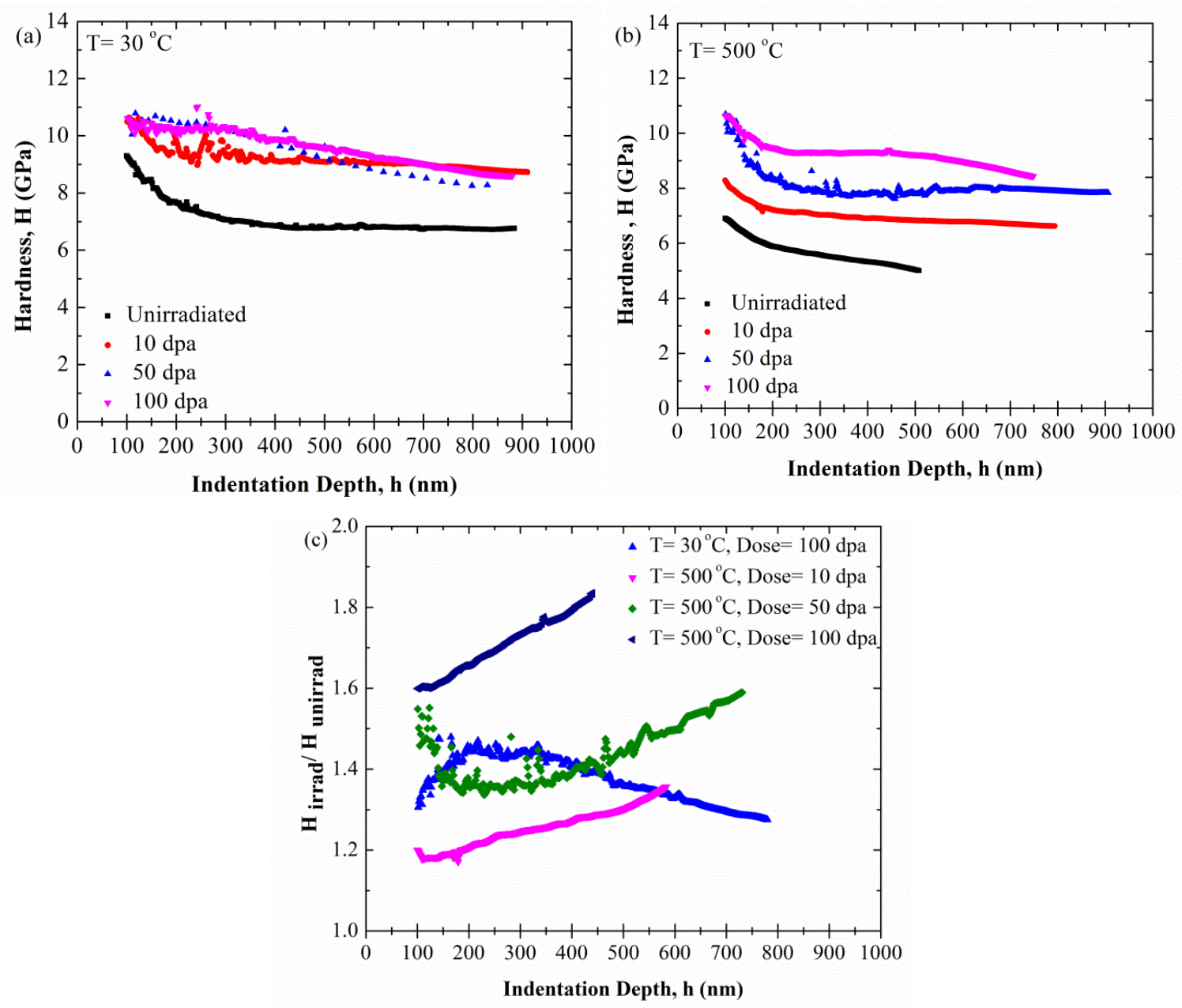

Figure 6 . The averaged hardness results obtained by using the multi-cycling method: (a) 0,10 , 50 and dpa at $30{ }^{\circ} \mathrm{C}$, (b) $0,10,50$, and $100 \mathrm{dpa}$ at $500{ }^{\circ} \mathrm{C}$ (each graph is averaged of 15 plots) and (c) $\mathrm{H}_{\text {irrad }} / \mathrm{H}_{\text {unirrad }}$ on indentation depth

Example indent regions in the unirradiated and irradiated samples are shown in Fig. 12(a-b), respectively. A FIB lift-out was conducted at a region adjacent to the indent in the irradiated sample $\left(500{ }^{\circ} \mathrm{C}, 100 \mathrm{dpa}\right)$ shown in Fig. 12 (b). The deformed microstructure was observed using TEM and included in Fig. 12(c). No clear evidence of localized deformation or dislocation channeling was observed, and the plastic deformation was found to be uniform. This could explain the absence of any saturation in hardening for the irradiated $500^{\circ} \mathrm{C}$ sample. High dislocation activity including significant dislocation/particle interaction was observed in the deformed microstructure. A combination of nanoparticles interacting with the dislocations, and 
high density of grain boundary areas could efficiently provide sink sites for the dislocations. No strain-induced grain growth was observed in the nanocrystalline region.

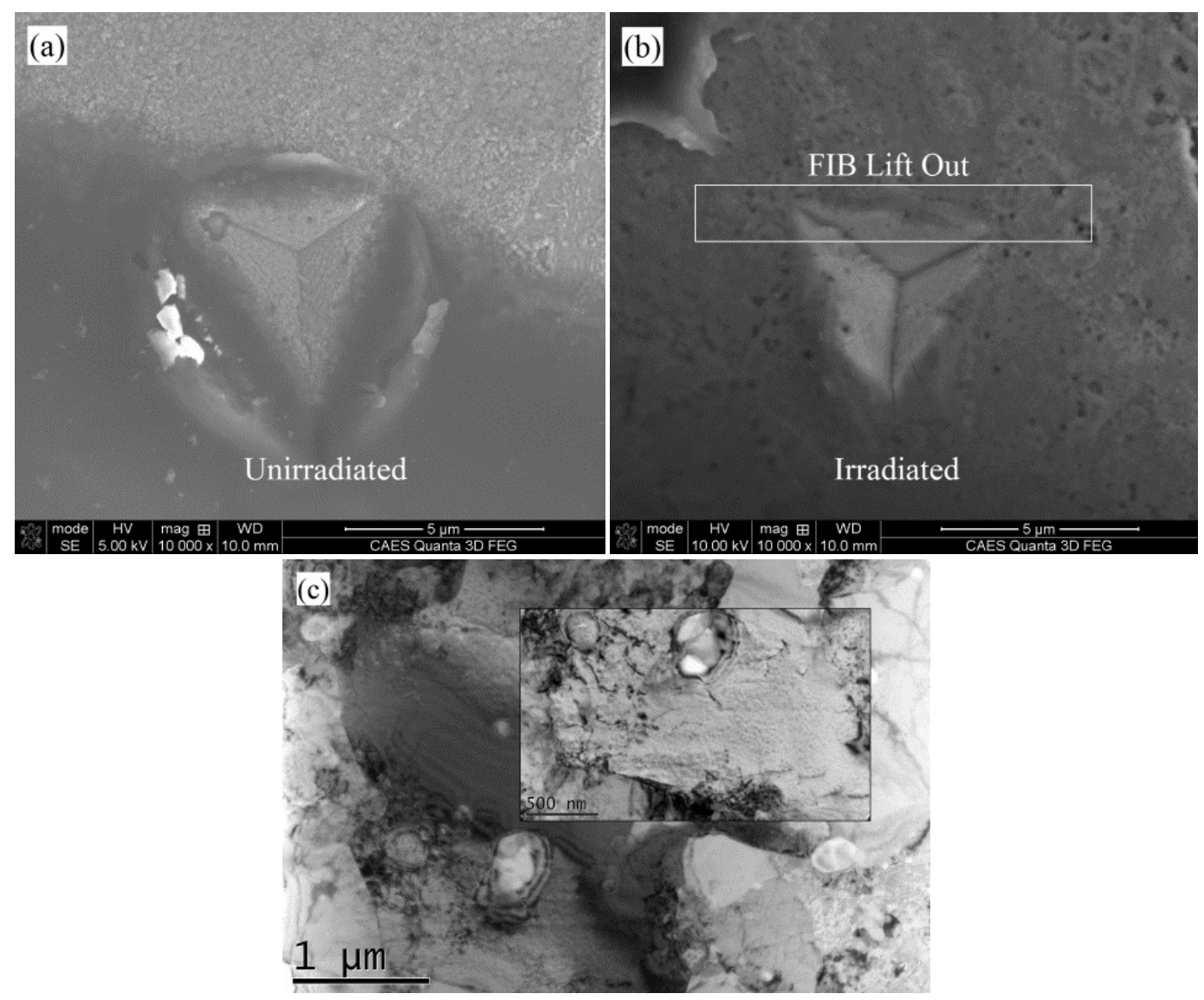

Figure 7. SEM micrographs showing the deformed region in the vicinity of indent:

(a) unirradiated sample and (b) irradiated at $500{ }^{\circ} \mathrm{C}$ for $100 \mathrm{dpa}$; the white rectangular region represents the area for FIB lift out and (c) the TEM BF micrograph from the FIB lift-out displaying the deformed microstructure in the vicinity of indent as shown in (b); the inset micrograph in (c) is from the same region taken at a higher magnification.

\section{Summary and conclusions}

Heavy self-ion $\left(\mathrm{Fe}^{2+}\right)$ irradiation experiments were performed at $30^{\circ} \mathrm{C}$ and $500^{\circ} \mathrm{C}$ with 10,50 and $100 \mathrm{dpa}$ doses on a lanthana-bearing nanostructured ferritic steel, 14LMT. The microstructure and hardness of the irradiated samples were evaluated and compared with those of the unirradiated sample. The overall grain structure and dislocation configuration did not 
exhibit any significant changes from thermal treatments to $500^{\circ} \mathrm{C}$ or ion irradiation. No clear evidence of dislocation loops or void swelling was found in the irradiated samples. The dislocation density constantly increased with increasing irradiation dose causing hardening across the entire irradiation damage depth. The high number density of the La-Ti-O-enriched particles could play a significant role in stabilizing the dislocation configurations by acting as sites for defect recombination. The shape, morphology and number density of NCs did not reveal any significant changes after irradiation up to $100 \mathrm{dpa}$. The radius of NCs, however, decreased slightly after elevated temperature irradiation at $500^{\circ} \mathrm{C}$ and 100 dpa. The $\mathrm{Cr}$ and $\mathrm{La}$ concentration of NCs was found to be higher, and Ti concentration of NCs was lower than that of the starting material after irradiation at $500^{\circ} \mathrm{C}$ and $100 \mathrm{dpa}$. Significant irradiation hardening occurred in all the irradiated samples. The hardening after irradiation at $30^{\circ} \mathrm{C}$ showed saturation after $50 \mathrm{dpa}$ and above. This saturation was not observed at $500^{\circ} \mathrm{C}$, and the irradiation induced hardening and dislocation density constantly increased at higher doses.

\section{Acknowledgements}

The work was supported by the U.S. Department of Energy, Office of Nuclear Energy under DOE Idaho Operations Office Contract DE-AC07-05ID14517, as part of Advanced Test Reactor National Scientific User Facility (ATR NSUF) experiments. The authors gratefully acknowledge the assistance of Dr. Yaqiao Wu, Joanna Taylor and Bryan Forsmann at the Microscopy and Characterization Suite (MaCS) facility of the Center for Advanced Energy Studies (CAES). The Texas A\&M group (LS and LP) acknowledge the support by the US Department of Energy through grant DE-NE0008297. 


\section{References}

[1] T.R. Allen, J. Gan, J.I. Cole, M.K. Miller, J.T. Busby, S. Shutthanand, S. Thevuthasan, J. Nucl. Mater., 375 (2008) 26-37.

[2] M.K. Miller, C.M. Parish, Mater. Sci. Technol., 27 (2011) 729-734.

[3] M.J. Alinger, G.R. Odette, D.T. Hoezler, Acta Mater., 57 (2009) 392-406.

[4] N. Akasaka, S. Yamashita, T. Yoshitake, S. Ukai, A. Kimura, J. Nucl. Mater., 329-333 (2004) 1053-1056.

[5] R.L. Klueh, P.J. Maziasz, I.S. Kim, L. Heatherly, D.T. Hoelzer, N. Hashimoto, E.A. Kenik, K. Miyahara, J. Nucl. Mater., 307 (2002) 773-777.

[6] H. Kishimoto, K. Yutani, R. Kasada, O. Hashitomi, A. Kimura, J. Nucl. Mater., 367-370 (2007) 179-184.

[7] J.J. Fisher, Patent, U.S.A. (1978).

[8] M.K. Miller, D.T. Hoelzer, E.A. Kenik, K.F. Russell, J. Nucl. Mater., 329-333, Part A (2004) $338-341$.

[9] G.R. Odette, M.J. Alinger, B.D. Wirth BD, Annu. Rev. Mater. Res., 38 (2008) 471-503.

[10] S. Yamashita, S. Ohtsuka, N. Akasaka, S. Ukai, S. Ohnukiy, Phil. Mag. Let., 84 (2004) $525-529$.

[11] C. Robertson, B.K. Panigrahi, S. Balaji, S. Kataria, Y. Serruys, M.H. Mathon, C.S. Sundar, J. Nucl. Mater., 426 (2012) 240-246. 
[12] E.A. Marquis, S.Lozano-Perez, V.de Castro, J. Nucl. Mater., 417 (2011) 257-261.

[13] S. Pasebani, I. Charit, D.P. Butt, J.I. Cole, J. Nucl. Mater., 434 (2013) 282-286.

[14] S. Pasebani, I. Charit, J. Alloy. Compd., 599 (2014) 206-211.

[15] M. Suárez, A. Fernández, J.L. Menéndez, R. Torrecillas, H. U. Kessel, J. Hennicke, R. Kirchner, T. Kessel, Sintering Applications- Challenges and Opportunities for Spark Plasma Sintering: A Key Technology for a New Generation of Materials, In Tech, 2013.

[16] J.G. Juárez, D.V. Jaramillo, R.A. Cuenca, F. L. Juárez, Powder Technol., 221 (2012) 264270.

[17] A. Certain, S. Kuchibhatla, V. Shutthanandan, D.T. Hoelzer, T.R. Allen, J. Nucl. Mater., 434 (2013) 311-321.

[18] G.S. Was, Z. Jiao, E. Beckett, K. Sun, A.M. Monterrosa, S.A. Maloy, O. Anderoglu, B.H. Sencer, M. Hackett, Scipta Mater., 452 (1-3) (2014) 328-334.

[19] http://www.srim.org

[20] L. Shao, C.C. Wei, J. Gigax, A. Aitkaliyeva, D. Chen, B.H. Sencer, F.A. Garner, J. Nucl. Mat. 453 (2014) 176-181.

[21] C.A. Williams, D. Haley, E.A. Marquis, G.D. Smith, M.P. Moody, Ultramicroscopy 132 (2013) 271-278.

[22] M.K. Miller, Atom probe tomography, Kluwer Academic / Plenum Publishers, NewYork, 2000 . 
[23] S.J. Zinkle, P. J. Maziasz, R. E. Stoller, J. Nucl. Mater., 206 (1993) 266-286.

[24] G. Was, Fundamentals of Radiation Materials Science: Metals and Alloys, Springer, Berlin, 2007.

[25] R. Bullough, M.R. Hayns, C.H. Woo, J. Nucl. Mater., 84 (1979) 93-100.

[26] A.W. Bowen, G.M. Leak, Metal. Trans., 1 (1970) 2767-27723.

[27] G. B. Gibbs, Trans. TMS-AIME, 239 (1967) 236.

[28] P. Pareige, M.K. Miller, R.E. Stoller, D.T. Hoelzer, E. Cadel, B. Radiguet, J. Nucl. Mater., 360 (2007) 136-142.

[29] I. Monnet, P. Dubuisson, Y. Serruys, M.O. Ruault, O. Kaitasov, B. Jouffery, J. Nucl. Mater., 335 (2004) 311-321.

[30] P. Hosemann, D. Kiener, Y. Wang, S.A. Maloy, J. Nucl. Mater., 425 (2012) 136-139.

[31] C. Liu, C. Yu, N. Hashimoto, S. Ohnuki, M. Ando, K. Shiba, S. Jitsukawa, J. Nucl. Mater., 417 (2011) 270-273.

[32] D. Kaomi, A. Motta, M. Kirk, Transactions of the American Nuclear Society, Anaheim, CA., 98 (2008).

[33] K. Asano, Y. Kohno, A. Kohyama, T. Suzuki, H. Kusanagi, J. Nucl. Mater., 155-157 (1988) 928-934.

[34] E.A. Little, D.J. Mazey, W. Hanks, Scripta Metall. Mater., 25 (1991) 1115-1118.

[35] C.L. Chen, A. Richter, R. Kögler, J. Alloy. Compd., 586 (2014) S173-S179. 
[36] C.A. Williams, M.J. Hyde, G.D. Smith, E.A. Marquis, J. Nucl. Mater., 412 (2011) $100-105$.

[37] H. Kishimoto, R. Kasada, O. Hashitomi, A. Kimura, J. Nucl. Mater., 386-388 (2009) 533536.

[38] C.H. Zhang, Y.T. Yang, Y. Song, J. Chen, L.Q. Zhang, J. Jang, A. Kimura, J. Nucl. Mater., 455 (2014) 61-67.

[39] Y. Zhanbing, H. Benfu, H. Kinoshita, H. Takahashi, S. Watanabe, J. Nucl. Mater., 398 (2010) 81-86.

[40] M.L. Lescoat, J. Ribis, A. Gentils, O. Kaïtasov, Y. de Carlan, A. Legris, J. Nucl. Mater., 428 (2012) 176-182.

[41] M.L. Lescoat, I. Monnet, J. Ribis, P. Dubuisson, Y. de Carlan, J.M. Costantini, J. Malaplate, J. Nucl. Mater., 417 (2011) 266-269.

[42] J. Ribis, M.L. Lescoat, Y. de Carlan, J.M. Costantini, I. Monnet, T. Cozzika, F. Delabrouille, J. Malaplate, J. Nucl. Mater., 417 (2011) 262-265.

[43] V. de Castro, M. Briceno, S. Lozano-Perez, P. Trocellier, S.G. Roberts, R. Pareja, J. Nucl. Mater., 445 (2014) 157-161.

[44] V.A. Skuratov, V.V. Uglov, J. O’Connell, A.S. Sohatsky, J.H. Neethling, S.V. Rogozhkin, J. Nucl. Mater., 442 (2013) 449-457.

[45] J. He, F. Wan, K. Sridharan, T.R. Allen, A. Certain, V. Shutthanandan, Y.Q. Wu, J. Nucl. Mater., 455 (2014) 41-45. 
[46] P. Dubusisson, R. Schill, M.P. Hugon, I. Grislin, J.L. Seran, R.K. Nanstad, M.L. Hamilton, F.A. Garner, A.S. Kumar, Effects of Radiation in Materials: 18th International Symposium, ASTM STP, West Conshohocken, PA (1999). 